\title{
15. THECOSOMATA (PTEROPODS) AND THEIR REMAINS IN LATE QUATERNARY DEPOSITS ON THE BOUGAINVILLE GUYOT AND THE CENTRAL NEW HEBRIDES ISLAND ARC ${ }^{1}$
}

\author{
Georgette Glaçon, ${ }^{2}$ Jeannine Rampal, ${ }^{3}$ Danièle Gaspard, ${ }^{4}$ Delhi Guillaumin,,${ }^{5}$ and Thomas Scott Staerker ${ }^{6}$
}

\begin{abstract}
We undertook a quantitative study of Thecosomata shells (pelagic gastropods) and their remains in Quaternary foraminiferal oozes deposited on the tilted calcareous platform of the Bougainville Guyot (Hole 831A), and in the late Quaternary volcanic siltstones, claystones and sandy interbeds on the upper forearc slope of the central New Hebrides Island Arc (Hole 830A). The distribution of the species is based on the identification of adult shells, juvenile stages, protoconchs, and characteristic shell fragments. By studying thecosomatous shells using a scanning electron microscope (SEM), we were able to specify the fine microstructure of the coiled Limacina inflata and compare it with the rod-type crossed-lamellar structure of some other Limacina species, as well as with the helical structure of the Cavoliniidae.
\end{abstract}

\section{INTRODUCTION}

Leg 134 of the Ocean Drilling Program investigated the collision between the d'Entrecasteaux Zone, a topographic high on the IndiaAustralia Plate, and the central New Hebrides Island Arc, a volcanic arc (Fig. 1). The Bougainville Guyot is the easternmost seamount of the South d'Entrecasteaux chain, which impinges upon the New Hebrides Island Arc near the latitude of Espiritu Santo Island (Vanuatu). Thecosomata occur in upper Quaternary sediments, on the Bougainville Guyot, and on the upper forearc slope of the central New Hebrides Island Arc.

Thecosomata are planktonic gastropods with coiled or uncoiled aragonitic shells. The occurrence of their shells distinguishes sediments deposited in open oceans above the aragonite compensation depth (ACD), a depth usually shallower than the foraminiferal lysocline and the calcite compensation depth (CCD) (Berger, 1977, 1978). Furthermore, since particular assemblages of Thecosomata species characterize different water masses in the oceans (Rampal, 1975; Be and Gilmer, 1977; Cifelli and McCloy, 1983), a study of changes in assemblages of species along undisturbed stratigraphical sections may reveal a turnover of the species in pelagic oozes that could indicate paleoclimatic changes useful for more detailed stratigraphic analyses (Chen, 1968; Herman and Rosenberg, 1969; Pastouret, 1970; Herman, 1971; Froget and Pastouret, 1972; Berger, 1977; Almogi-Labin, 1982; Almogi-Labin et al., 1986; Gardulski et al., 1990), and displacement or change in velocity of currents (Chen and Hillman, 1970).

\section{SAMPLES}

Twenty-four upper Quaternary sedimentary samples were selected aboard the ship for Thecosomata study. They came from the following three holes.

Hole $830 \mathrm{~A}$ is located $30 \mathrm{~km}$ south of the southern tip of Espiritu Santo Island, high on the upper forearc slope of the central New

\footnotetext{
${ }^{1}$ Greene, H.G., Collot, J.-Y., Stokking, L.B., et al., 1994. Proc. ODP, Sci. Results, 134: College Station, TX (Ocean Drilling Program).

${ }^{2}$ Chemin de Correns, La Caillade, 83570 Cotignac, France.

${ }^{3}$ Laboratoire de Biologie animale (Plancton), Université de Provence, Place Victor Hugo, 13331 Marseille Cedex 3, France.

${ }_{5}^{4}$ Université de Paris Sud, Département des Sciences de la Terre, Orsay Cedex, France.

${ }^{5}$ Service d'accueil du M.E.B. (CNRS-Paris VI), 105 Boulevard Raspail, 75006 Paris, France.

${ }^{6}$ Department of Geology, Florida State University, Tallahassee, FL 32306, U.S.A.
}

\begin{tabular}{cccc}
\hline Leg 134 & $\begin{array}{c}\text { Latitude } \\
\text { (south) }\end{array}$ & $\begin{array}{c}\text { Longitude } \\
\text { (east) }\end{array}$ & $\begin{array}{c}\text { Depth } \\
\text { (mbsf) }\end{array}$ \\
\hline Hole 830A & $15^{\circ} 57.00^{\prime}$ & $166^{\circ} 46.79^{\prime}$ & 1018.4 \\
Hole 831A & $16^{\circ} 00.51^{\prime}$ & $166^{\circ} 40.36^{\prime}$ & 1077.6 \\
Hole 833A & $14^{\circ} 47.77^{\prime}$ & $167^{\circ} 52.78^{\prime}$ & 2629.0 \\
\hline
\end{tabular}

Hebrides Island Arc on the northern wall of the $10 \mathrm{~km}$ bathymetric Malakula reentrant, an indentation caused by the impact of the Bougainville Guyot (Collot, 1989). Seven $20-\mathrm{cm}^{3}$ samples were selected aboard ship from 2.15 to 15.82 meters below seafloor (mbsf), $(1 \mathrm{H}-2$, $65-68 \mathrm{~cm}$, to $2 \mathrm{H}-6,132-134 \mathrm{~cm}$ ), all of which are from lithostratigraphic Subunit IA, a fine-grained, nearly structureless, unlithified, volcanic silt with normally graded foraminiferal sandy interbeds occurring below 10 mbsf (Collot, Greene, Stokking, et al., 1992).

Nannofossil zonation established by examination of the samples with a scanning electron microscope (SEM) is shown in Table 1. The lithostratigraphic report (Collot, Greene, Stokking, et al., 1992) indicates that the interval between Sample 830A-2H-3, 110-111 cm and Sample 830A-2H-4, 38-39 cm exhibits oxidation. Because this is also the interval across which the nannofossil Emiliania huxleyi first appears in the section, we propose that an unconformity may be present here.

Site 831 is located about $15 \mathrm{~km}$ due west of Site 830 , in the center of the carbonate-capped platform on the summit of Bougainville Guyot (Fig. 1). The seafloor trace of the subduction zone, as surveyed from the submersible Nautile (SUBPSO cruise, Collot et al., 1989; 1992; Montaggioni et al., 1991), crosses between sites 830 and 831 . Seventeen $15 \mathrm{~cm}^{3}$ samples from 0.81 to $28 \mathrm{mbsf}$ (831A-1H-1, 81-84 $\mathrm{cm}$ to $10 \mathrm{X}-\mathrm{CC}, 27-28 \mathrm{~cm}$ ), were selected on board. Samples from 0 to $16.4 \mathrm{mbsf}(831 \mathrm{~A}-1 \mathrm{H}, 0 \mathrm{~cm}$, to $3 \mathrm{H}-\mathrm{CC}, 6 \mathrm{~cm})$ are from lithostratigraphic Unit I, a foraminiferal ooze with grainstone clasts (Collot, Greene, Stokking, et al., 1992). The contact with lithostratigraphic Unit II is marked by an abrupt faunal transition from pelagic to neritic microfossils. The nannofossil zonation (Table 2) was established with the use of a light-microscope only.

The flow of sandy sediment into the hole degraded the quality of the advanced hydraulic piston core (APC) cores recovered (Collot, Greene, Stokking, et al., 1992). That is particularly true of Core 831A$2 \mathrm{H}$, where $2 \mathrm{~m}$ of drilling resulted in $9.64 \mathrm{~m}$ recovered.

Site 833 is located approximately $24 \mathrm{~km}$ northwest of the northern tip of Maewo Island, on the lower east-central flank of the North Aoba Basin, an intra-arc basin between the Western and Eastern belts of islands in the central New Hebrides Island Arc (Fig. 1). Three 10- $\mathrm{cm}^{3}$ 


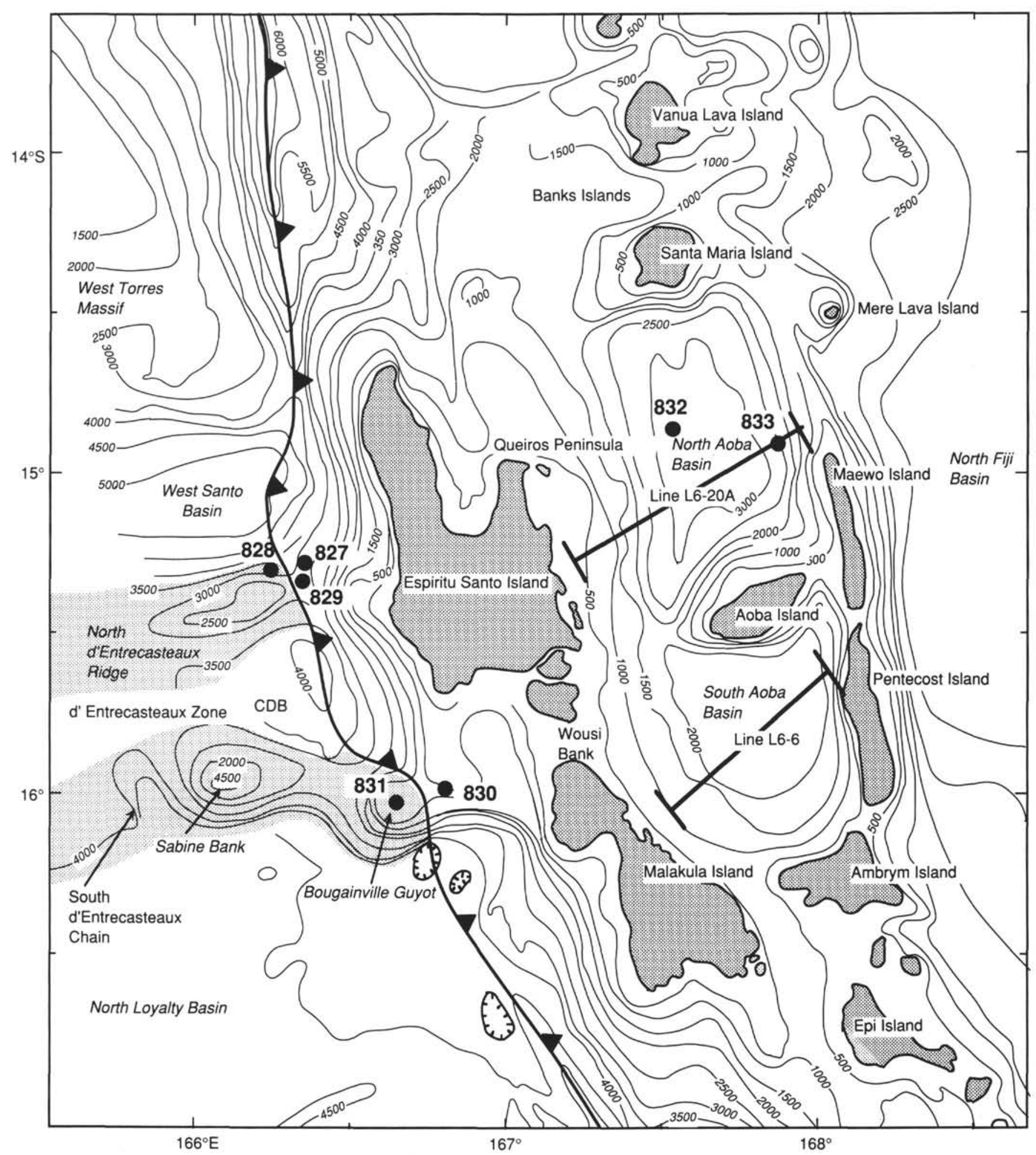

Figure 1. Index map showing Leg 134 drill sites. Bathymetry in meters. Line with teeth indicates plate boundary.

samples from 11.90 to 21.55 mbsf were selected on board ship. All are from lithostratigraphic Subunit IA, clayey to sandy volcanic silt interbedded with numerous volcanic layers (Collot, Greene, Stokking, et al., 1992). On board, the boundary between nannofossil Zones $\mathrm{CN} 15$ and $\mathrm{CN} 14$ was tentatively located in Core 833A-3H, between 18.9 and 28.5 mbsf.

\section{METHODS}

Samples of about 10 to $20 \mathrm{~cm}^{3}$ each were dried at $60^{\circ} \mathrm{C}$ for about $6 \mathrm{hr}$ and then weighed before being washed through a battery of sieves with mesh sizes of 500,150,125, and $63 \mathrm{~mm}$, respectively. Each size fraction was again dried and then weighed. The results are illustrated 
Table 1. Nannofossil zonation of samples from Hole 830A.

\begin{tabular}{|c|c|c|c|c|}
\hline $\begin{array}{l}\text { Core, section, } \\
\text { interval }(\mathrm{cm})\end{array}$ & $\begin{array}{l}\text { Depth } \\
\text { (mbsf) }\end{array}$ & $\begin{array}{c}\text { Nannofossil } \\
\text { event }\end{array}$ & $\begin{array}{l}\text { Nannofossil } \\
\text { zone }\end{array}$ & $\begin{array}{l}\text { Age } \\
\text { (Ma) }\end{array}$ \\
\hline $\begin{array}{l}134-830 \mathrm{~A}- \\
2 \mathrm{H}-3,110-111\end{array}$ & 11.10 & $\begin{array}{l}\text { E. huxleyi } \\
\text { (common) }\end{array}$ & $\mathrm{CN} 15$ & \\
\hline $2 \mathrm{H}-4,38-39$ & 11.88 & $\begin{array}{l}\text { E. huxleyi } \\
\text { (absent) }\end{array}$ & $\begin{array}{l}\text { Unconformity? } \\
\text { CN14b }\end{array}$ & \\
\hline $2 \mathrm{H}-6,30-31$ & 14.80 & $\begin{array}{l}\text { P. lacunosa } \\
\text { (absent) }\end{array}$ & $\mathrm{CN} 14 \mathrm{~b}$ & \multirow[b]{2}{*}{0.46} \\
\hline $2 \mathrm{H}-6,110-11 \mathrm{I}$ & 15.60 & $\begin{array}{r}\text { P. lacunosa } \\
\text { (common) }\end{array}$ & $\mathrm{CN} 14 \mathrm{a}$ & \\
\hline
\end{tabular}

Note: $E .=$ Emiliania,$P=$ Pseudoemiliania.

in Figures 2A, 3A, and 4A. Note that the sample intervals are too large to give a real representation of the evolution of grain size along the cores.

Using a JSM 840A SEM specimens coated with evaporated goldpalladium were examined to determine their state of preservation. To precisely define the microstructure of the shell walls we compared sections obtained using needles to more precisely oriented sections of shells embedded in araldite, then etched them for 1 or $2 \mathrm{~s}$ in "RBO" (Dupeage Kinetic Laboratory Illinois) at $12.5 \%$ (Pls. 2-6).

Quantitative analysis of the Thecosomata was performed on every sample with a fraction larger than $500 \mu \mathrm{m}$. Counts are summarized for Hole 830A in Table 3 and for Hole 831A in Table 4.

Some uncoiled Thecosomata are fragile. They are not always preserved as a whole shell. Therefore, we identified fragments of broken shells to note the occurrence of the species in the sediments. In Table 5 , and illustrated in Plate 1, we regroup the characteristic features of the teloconchs, protoconchs, or posterior spines of the principal species collected in the western Pacific. Morphological terms are illustrated by Be and Gilmer (1977); microstructural terms are defined and illustrated by Carter et al. (1991).

\section{RESULTS AND DISCUSSION}

Quaternary samples from Holes 830A and 831A contain Thecosomata; however, no Thecosomata remains have been found in the sandy fraction (larger than $63 \mu \mathrm{m}$ in grain size) of the samples selected on board at Hole 833A.

The number of Thecosomata larger than $500 \mu \mathrm{m}$ is strongly variable from sample to sample. Quantities ranged from less than 50 to nearly 20,000 individuals per $100 \mathrm{~g}$ of original sediment.

At Site 830, in nannofossil Zones CN15 and CN14b (less than 0.46 $\mathrm{Ma}$ ) the number of Thecosomata correlates crudely with the weight of the sandy fraction, except in Sample 830A-2H-1, 103-107 cm (8.02 mbsf), where volcanic material increases drastically (Figs. 2A, B). At that level, the scarcity of Thecosomata may reflect dilution by volcaniclastic sediment. At $15.82 \mathrm{mbsf}$ the lack of Thecosomata in a sample placed in nannofossil Zone $\mathrm{CN} 14$ a could be the result of transport with displacement of sandy particles, since silt and clay comprise more than $85 \%$ in weight of that sediment.

The downhole contamination of Core $831 \mathrm{~A}-2 \mathrm{H}$ observed on board prevents proper correlation of the sample in Hole 831 A (Fig. 3). In Core $831 \mathrm{~A}-3 \mathrm{H}$, however, the same crude correlation between the sandy fraction and the number of Thecosomata as found at Site 830 reappears (Fig. 4). It is clear that Thecosomata shells play an important role in the volume of the sandy fraction of the sediments in Hole 831A.

Eighteen species of Thecosomata have been identified in the studied samples. Their distribution is summarized for Hole $830 \mathrm{~A}$ in Table 3 and for Hole 831A in Table 4. These species are comparable to those identified by Be and Gilmer (1977) with the three exceptions of Cuvierina columnella, Cavolinia uncinata, and Creseis virgula (Table 6). In nannofossil Zone CN15 and in a Zone CN14b horizon,
Table 2. Nannofossil zonation of samples from Hole 831A.

\begin{tabular}{cccc}
\hline $\begin{array}{c}\text { Core, section, } \\
\text { interval (cm) }\end{array}$ & $\begin{array}{c}\text { Depth } \\
\text { (mbsf) }\end{array}$ & $\begin{array}{c}\text { Nannofossil } \\
\text { event }\end{array}$ & $\begin{array}{c}\text { Nannofossil } \\
\text { zone }\end{array}$ \\
\hline $\begin{array}{c}134-831 \mathrm{~A}- \\
1 \mathrm{H}-3,116-117\end{array}$ & 4.16 & $\begin{array}{c}\text { E. huxleyi (sparse) preser- } \\
\text { vation declines } \\
\text { SEM analysis was required } \\
\text { for positive identification } \\
\text { of } E \text {. huxleyi }\end{array}$ & $\mathrm{CN} 15$ \\
Too few nannofossils & $\mathrm{CN} 15$ \\
$3 \mathrm{H}-7,39-40$ & 15.80 & "Soupy" & \\
\hline
\end{tabular}

in Hole 830A Styliola subula is the dominant species, comprising more than $75 \%$ of the Thecosomata. Very rare Limacina inflata appear in scattered horizons and are in agreement with the distribution of living forms (Table 6). Styliola subula is always present in Hole 831A, but its percentage varies from $5 \%$ to $88 \%$. Limacina inflata is usually the preponderant species, comprising $42 \%-85 \%$ of the Thecosomata present in poorly preserved nannofossil assemblages identified as Zone CN15 (Table 2). In Samples 831A-3H-5, 75-80 cm, and 3H-2, $75-80 \mathrm{~cm}$, however, Styliola subula is dominant with $88 \%$ and $54 \%$ of the Thecosomata, respectively.

The state of shell preservation varies. Coiled forms, such as Limacina species, are usually well-preserved, but ornamentation is missing from the very rare Peraclis. Uncoiled forms, such as Diacria and Cavolinia, are often open, with dorsal and ventral parts of the shell separated. Clio, Styliola and Creseis are always subtransversally broken, and Hyalocylis is strongly fragmented. Various protoconchs isolated by breakage occur. Many protoconchs and fragments are specifically identifiable. Plates $1 \mathrm{~A}, 1 \mathrm{~B}$, and Table 5 show useful indices for identifying shells or fragments of shells.

Shell damage may result from compaction, transport, biodegradation, or dissolution. However, Berger and Piper (1972) argue that for calcitic foraminiferal tests "it could be difficult to differentiate between dissolution and transport since sediments containing only heavy resistant shells may result from dissolution of less resistant tests or from bottom currents winnowing out the lighter shells." We used the SEM to distinguish between mechanically damaged, biodegraded, and partly dissolved shells. Borings are rare and small. No strong dissolution indices occur, and we can easily observe the characteristic microstructures of the fragmented walls.

Preservation of shell microstructures provides an excellent opportunity to study thecosomatous fragments using the SEM. Previous microstructural descriptions differ on certain points. For a detailed ultrastructural study using the SEM, Be et al. (1972) selected Cuvierina columnella (Rang) because "of its relatively uncomplicated shape, resembling a cylindrical bottle and because its structure-prismatic and helical-is characteristic of that of other pteropod species: $\mathrm{Li}$ macina inflata, L. bulimoides, Euclio pyramidata, Creseis virgula, Styliola subula, Hyalocylis striata, Diacria trispinosa, and Cavolinia longirostris." In an addendum to their study on Cuvierina columnella they suspected "Limacina bulimoides to have crossed-lamellar, not helical structure." Rampal (1972, 1973, 1974, 1975, 1977) distinguishes the prismatic and/or crossed-lamellar shell structure of the Limacinidae ( $\mathrm{Pl} .2$ ) from the prismatic and spiral structure of the Cavoliniidae. Following Rampal $(1973,1975)$, the differences in microarchitectural structures of the shell are critical to phylogeny. The uncoiling of coiling forms induces the inner helical microstructure. Richter (1976) recognized the helical structure of Limacina inflata and Cavoliniidae. Be and Gilmer (1977) pointed out that "the shells of the Limacinidae (coiled forms) and Cavoliniidae (uncoiled forms) are constructed of aragonite, but their microstructures are strikingly different. The Limacinidae, with the possible exception of Limacina inflata, possess a crossed-lamellar shell microstructure. In contrast, the Cavoliniidae have a helical microstructure that is unlike that of any other molluscan group." Poulicek et al. (1991) also re-examined 
A

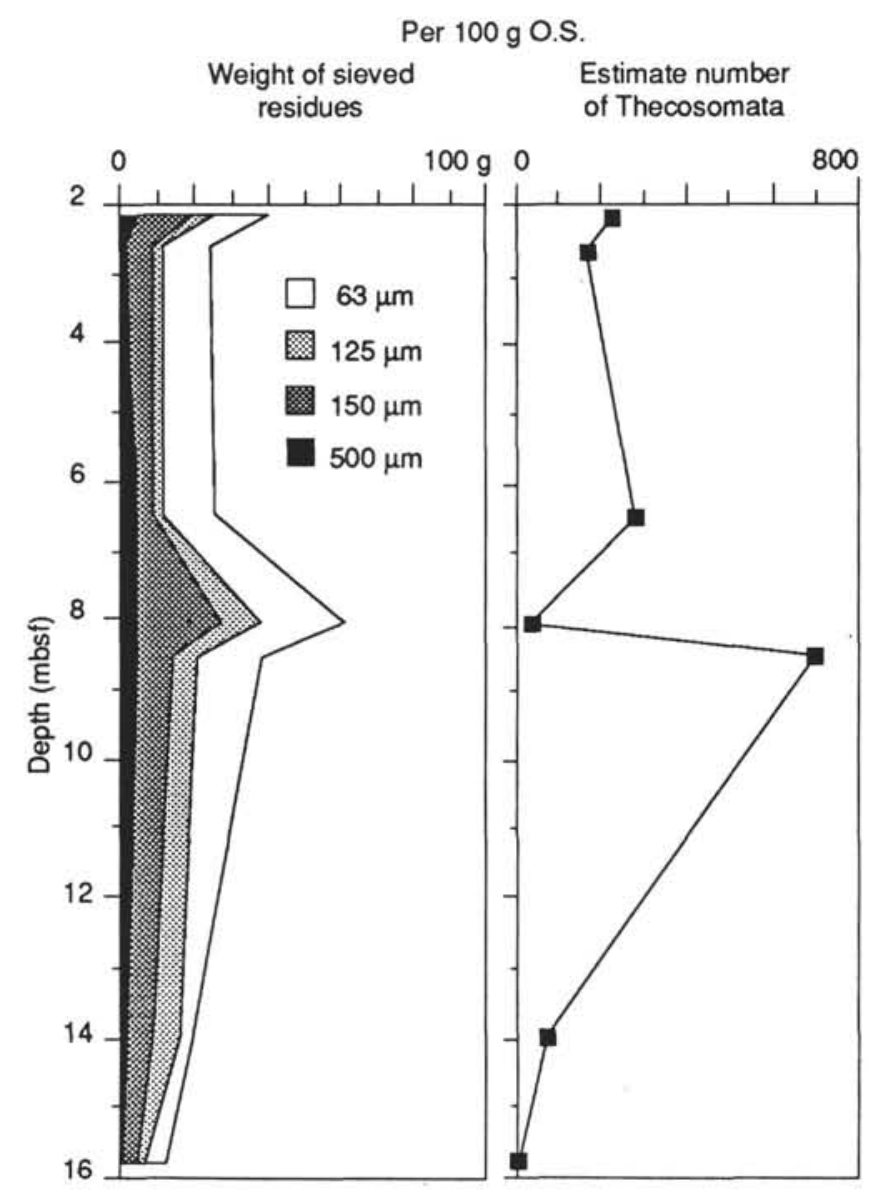

C

In O.S.

Number of
Number of
species

0

120

150

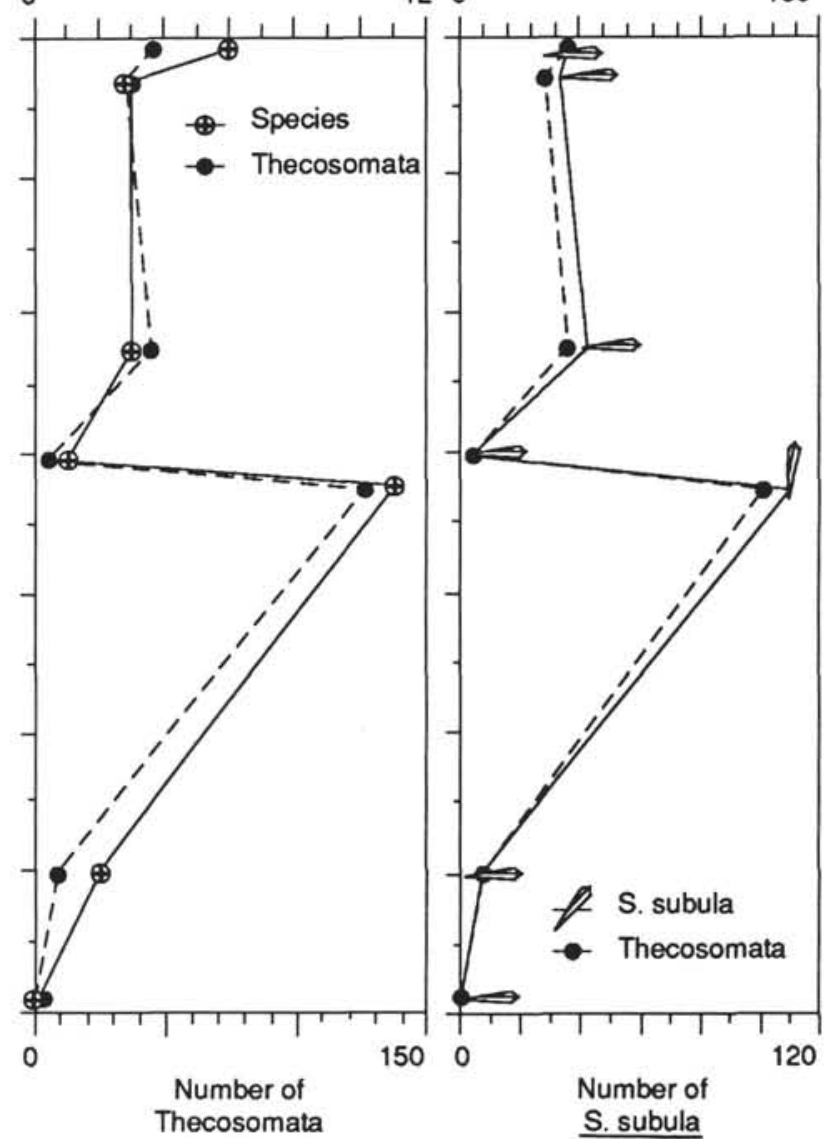

Figure 2. The distribution of Thecosomata and their species in Hole 830A core samples. A. Variation in the weight of residues per $100 \mathrm{~g}$ original sample (OS) from every sieve, using $63,125,150$, and $500 \mu \mathrm{m}$ mesh-size sieves. B. Estimate of the number of Thecosomata larger than $500 \mu \mathrm{m}$ per $100 \mathrm{~g}$ original samples. C. Comparison of the number of Thecosomata and the number of species found in the original sample. D. Comparison of the number of Styliola subula and the number of Thecosomata in original samples.

Limacina inflata and concluded that "under a thin granular layer there are two poorly individualized layers of somewhat disorganized crossed acicular-fabric." We note that they studied "pieces of shell cut from the last whorl some distance away from the aperture." That could explain why they do not describe the helical structure we found in previous coiling turns of the shell (Pls. 3,4), which compares well with the helical structure of Cavoliniidae (Pls. 5, 6). If we compare the coiling mode of the species (Pl. 4, Figs. 8-11) we see that the tightly coiled, high-spired Limacina bulimoides has a more closely crossed-lamellar shell than the others. Adult $L$. inflata is flat with the apex invisible in profile view. It has fewer coils and a spire that grows faster than in other Limacina. Perhaps the tendency to become uncoiled could be hypothesized.

The microstructure of a thecosomatous shell varies according to the area observed. That is clearly demonstrated for Cuvierina columnella by Be et al. (1972). In Plates 3 and 4 we show Limacina inflata with the prismatic layer close to the aperture and the helical layer (one turn) formed away from the aperture. Another prismatic layer different from that of the aperture- the prisms are shorter-occurs below the helical layer in the inner part of cross sections. Crossed-acicular structure (sensu Carter) seems to occur close to the aperture (Pl. 3,
Fig. 1). Poulicek et al. (1991) stated "apart from Limacina inflata, the shells of Creseis acicula, Hyalocylis striata, Euclio pyramidata, Diacria trispinosa and Cavolinia longirostris are built, following the same scheme: under a thin granular layer, there is a crossed-acicular layer progressively becoming helicoidal close to the inner side of the shell." The Cavoliniidae we illustrate are all of the helical type, but we distinguished species with one helical turn (Pl. 5) from species with multi-helical turns (Pl. 6).

\section{SUMMARY}

From the quantitative study of thecosomatous shells in late Quaternary sediments of Holes 830A and 831A, Zones CN15-CN14b, we note some changes in thecosomatous distribution. Styliola subula is always present and usually abundant, but Limacina inflata declines from $0.46 \mathrm{Ma}$ until the Holocene.

The fragmentation of many shells provided an opportunity to determine how to identify species from protoconchs, juvenile stages, or shell fragments only. The type of shell fragmentation is characteristic of the species. Fragmentation more often seems to be mechanically induced rather than the result of differential dissolution or 
A

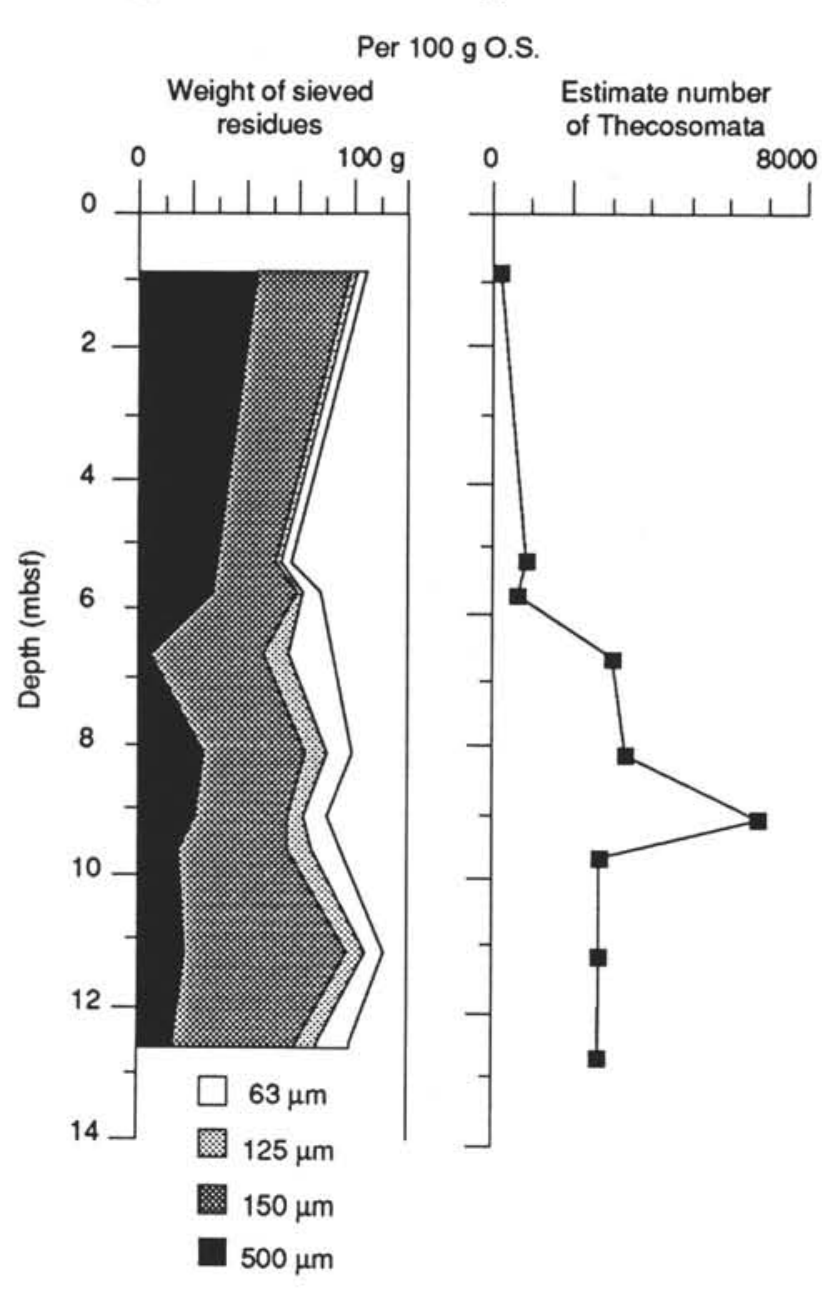

C

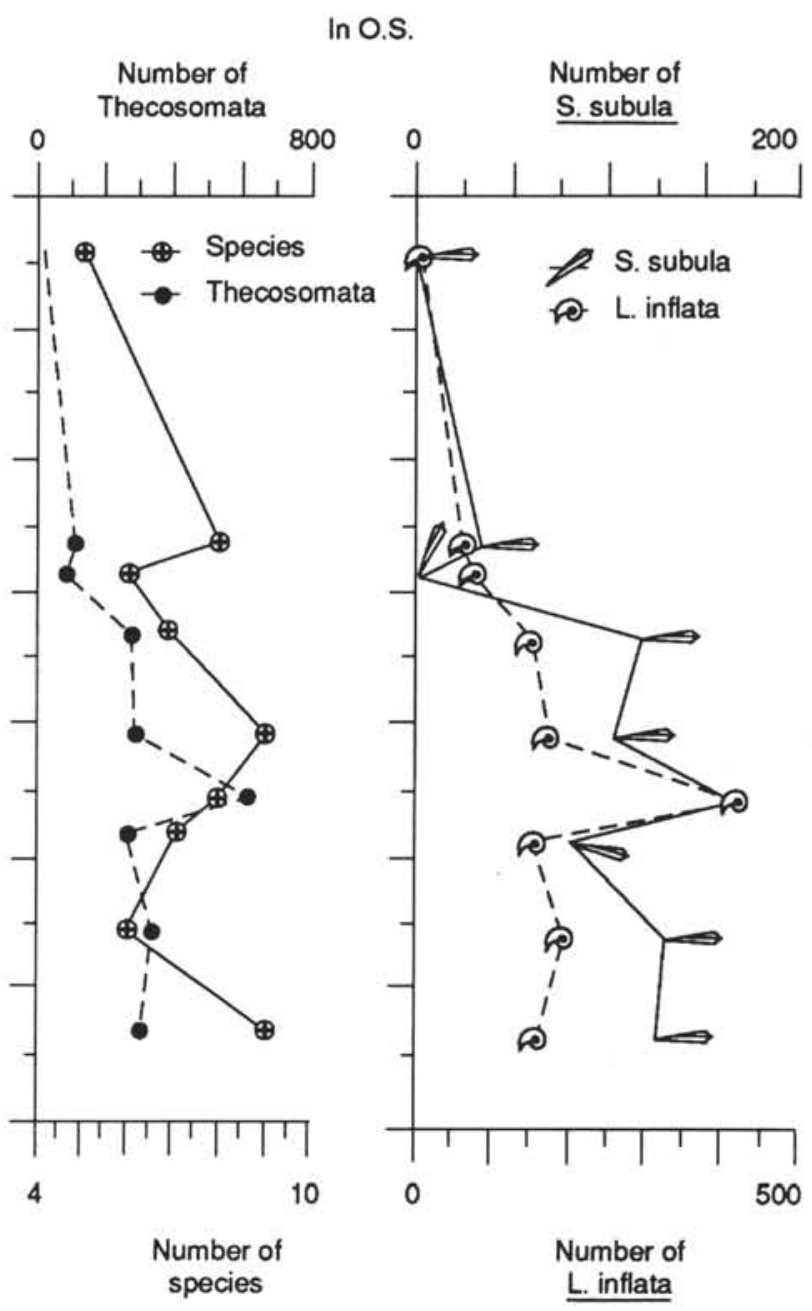

Figure 3. The distribution of Thecosomata and their species in samples from Cores $831 \mathrm{~A}-1 \mathrm{H}$ and $-2 \mathrm{H}$. A. Variation in the weight of residues per $100 \mathrm{~g}$ original sample (OS) from every sieve, using $63,125,150$, and $500 \mu \mathrm{m}$ mesh-size sieves. B. Estimate of the number of Thecosomata per $100 \mathrm{~g}$ of original samples. C. Comparison of the number of Thecosomata and the number of species found in original samples. D. Comparison of the frequency of Limacina inflata and Styliola subula in original samples. In Table 4 we noted the "soupy" nature of some samples from Core 831A-2H. Two meters of drilling resulted in $9.64 \mathrm{~m}$ recovered core. Thus, to plot Thecosomata frequency vs. sand size fraction from samples of Core 831A-2H, we use the apparent "soupy depths" to properly place the samples in the expanded core.

biodegradation. The state of preservation of the microstructure of shell walls was studied using the SEM. Thecosomata show ontogenic changes in shell structure. The microstructure of the coiled Limacina inflata compares well with the helical structure of uncoiled Cavoliniidae, in opposition to the rod-type crossed lamellar structure observed in other coiled Limacina, L. bulimoides, L. lesueuri, and L. trochiformis. This particular structure of Limacina inflata could be an index of its key location on the phyletic tree of uncoiled Thecosomata, like Creseis, Hyalocylis striata, and Styliola subula.

\section{ACKNOWLEDGMENTS}

We are indebted to the Ocean Drilling Program and the U.S. National Science Foundation for providing samples. We thank those who sampled for us on board ship. The authors greatly acknowledge J.-Y. Collot, H. G. Greene, M. Poulicek, and S. van der Spoel for their constructive criticism. L. Dearmont greatly improved the original manuscript. We also wish to thank M. Lécorché for help, particularly with the computer graphics, and J.-J. Cornée and J.-P. Saint Martin for interesting discussions. The Institut National des Sciences de l'Univers (INSU) provided G. Glaçon with funds to attend the Scientific Meeting in Villefranche-sur-Mer. Unité de Recherches Associées 1208 (URA) helped in printing the draft of this manuscript.

\section{REFERENCES}

Almogi-Labin, A., 1982. Stratigraphic and Palaeo-oceanographic significance of late Quaternary pteropods from deep sea cores in the gulf of Aqaba (Elat) and Northern Red Sea. Mar. Micropaleontol., 7:53-72.

Almogi-Labin, A., Luz, B., and Duplessy, J.-C., 1986. Quaternary paleooceanography, pteropod preservation and stable-isotope record of the Red Sea. Palaeogeogr., Palaeoclimatol. Palaeoecol., 57:195-211.

\footnotetext{
- Abbreviations for names of organizations and publications in ODP reference lists follow the style given in Chemical Abstracts Service Source Index (published by American Chemical Society).
} 
Bé, A.W.H., and Gilmer, R.W., 1977. A zoogeographic and taxonomic review of Euthecosomatous pteropoda. In Ramsay, A.T.S. (Ed.), Oceanic Micropaleontology (Vol. 1): New York (Academic Press), 1:733-808.

Bé, A.W.H., MacClintock, C., and Currie, D.C., 1972. Helical shell structure and growth of the pteropod Cuvierina columnella (Rang) (Mollusca, Gastropoda). Biominer. Res. Rep., 4:47-79.

Berger, W.H., 1977. Deep-sea carbonate and deglaciation preservation spike in pteropods and foraminifera. Nature, 269:301-304.

, 1978. Deep-sea carbonate: pteropod distribution and the aragonite compensation depth. Deep-Sea Res. Part A, 25:447-452.

Berger, W.H., and Piper, D.J.W., 1972. Planktonic foraminifera: differential settling, dissolution and redeposition. Limnol. Oceanogr., 17:275-287.

Carter, J.G., Bandel, K., de Buffrenil, V., Carlson, S., Castanet, J., Dalingwater, J., Francillon-Vieillot, H., Geraudie, J., Meunier, F.J., Mutvei, H., de Ricqles, A., Sire, J.Y., Smith, A., Wendt, J., Williams, A., and Zylberberg, L., 1991. Glossary of skeletal biomineralization. In Carter, J.G. (Ed.), Skeletal Biomineralization: Patterns, Processes and Evolutionary Trends. Am. Geophys. Union, Short Course in Geol., 5:337-355.

Chen, C., 1968. Pleistocene pteropods in pelagic sediments. Nature, 219: $1145-1149$.

Chen, C., and Hillman, N.S., 1970. Shell-bearing pteropods as indicators of water masses off Cape Hatteras, North Carolina. Mar. Sci. Bull., 20:350-367.

Cifelli, R., and McCloy, C., 1983. Planktonic foraminifera and Euthecosomatus pteropods in the surface waters of the North Atlantic. J. Foraminiferal Res., 13:91-107.

Collot, J.-Y., 1989. Obduction et collision: exemples de la Nouvelle Calédonie et de la zone de subduction des Nouvelles-Hébrides [Thèse de Doctorat d'Etat]. Orsay.

Collot, J.-Y., Greene, H.G., Stokking, L.B., et al., 1992. Proc. ODP, Init. Repts., 134: College Station, TX (Ocean Drilling Program).

Collot, J.-Y, Lallemand, S., Pelletier, B., Eissen, J.-P, Glaçon, G., Fisher, M.A., Greene, H.G., Boulin, J., Daniel, J., and Monzier, M., 1992. Geology of the d'Entrecastaux-New Hebrides island arc collision: results from a deep-sea submersible survey. Tectonophysics, 212:213-241.

Collot, J.-Y., Pelletier, B., Boulin, J., Daniel, J., Eissen, J.P., Fisher, M.A., Greene, H.G., Lallemand, S., and Monzier, M., 1989. Premiers résultats des plongees de la campagnee SUBPSOI dans la zone de collision des rides d'Entrecasteaux et de l'arc des Nouvelles Hébrides. C. R. Acad. Sci. Ser. 2, 309:1947-1954.

Froget, C., and Pastouret, L., 1972. Les Ptéropodes, moyen d'étude de la climatologie quaternaire. Comparaison de deux carottes prélevées en Méditerranée occidentale et orientale. Rapp. Comm. Int. Mer Mediter., 20:611-614.
Gardulski, A.F., Mullins, H.T., and Weiterman, S., 1990. Carbonate mineral cycles generated by foraminiferal and pteropod response to Pleistocene climate: West Florida ramp slope. Sedimentology, 37:727-743.

Herman, Y., 1971. Vertical and horizontal distribution of pteropods in Quaternary sequences. In Funnel, B.M., and Riedel, W.R. (Eds.), The Micropaleontology of the Oceans: Cambridge (Cambridge Univ. Press), 463-486.

Herman, Y., and Rosenberg, P.F., 1969. Pteropods as bathymetric indicators. Mar. Geol., 7:169-173.

Montaggioni, L., Butterlin, J., Glaçon, G., Collot, J.-Y., Monzier, M., Pelletier, B., Boulin, J., Lallemand, S., Daniel, J., Faure, G., Lauriat-Rage, A., Vénec-Peyré, M.-T., Blondeau, A., Lozouet, P., Vacelet, J., and Babinot, J.-F., 1991. Signification géodynamique des calcaires de plate-forme en cours de subduction sous l'Arc des Nouvelles-Hébrides (sud-ouest de l'Océan Pacifique). C. R. Acad. Sci. Ser. 2, 313:661-668.

Pastouret, L., 1970. Etude sédimentologique de carottes prélevées en Méditerranée orientale. Tethys, 2:227-266.

Poulicek, M., Voss-Foucart, M.-F., and Jeuniaux, C., 1991. Regressive shell evolution among opisthobranch gastropods. Malacologia, 32:223-232.

Rampal, J., 1972. Structure de la coquille des Ptéropodes au microscope à balayage. Comm. Int. Mer. Mediter., $23^{\circ}$ Reunion Assoc. Plen., Comité du Plancton, Athènes 1972.

_ 1973. Phylogénie des Ptéropodes Thécosomes d'après la structure de la coquille et la morphologie du manteau. C. R. Acad. Sci. Ser. 2, 277:1345-1348.

, 1974. Structure de la coquille des Ptéropodes au microscope à balayage. Rapp. Comm. int. Mer Médit., 22-9:133-134.

, 1975. Les Thécosomes (Mollusques pélagiques). Systématique et évolution. Ecologie et Biogéographie méditerranéenne [Thèse de Doctorat d'Etat]. Univ. de Provence, Marseille.

1977. Diversité de structure de la coquille chez les Thécosomes (Mollusca). Atti Soc. Ital. Sci. Nat. Museo Civ. Stor. Nat. Milano, 118: 207-211.

, 1985. Systématique du genre Creseis (Mollusques, Thécosomes) Rapp. Comm. Int. Mer Mediter., 29:259-263.

Richter, G., 1976. Zur Frage der Verwandtschaftsbeziehungen von Limacinidae und Cavolinidae. Arch. Moll., 107:137-144.

Date of initial receipt: 9 April 1992

Date of acceptance: 18 December 1992

Ms 134SR-014

Table 3. Number of identified Thecosomata in sieved residues larger than $500 \mu \mathrm{m}$ in grain size from Hole 830A samples.

\begin{tabular}{|c|c|c|c|c|c|c|c|}
\hline Section $134-830 \mathrm{~A}$ - & IH-2 & $1 \mathrm{H}-2$ & 1H-5 & $2 \mathrm{H}-1$ & $2 \mathrm{H}-2$ & $2 \mathrm{H}-52$ & H-6 \\
\hline Sample interval $(\mathrm{cm})$ & $65-68$ & $111-114$ & $49-52$ & $103-107$ & $2-6$ & $95-97$ & $132-134$ \\
\hline \multirow{4}{*}{$\begin{array}{l}\text { Depth (mbsf) } \\
\text { Graphic lithology } \\
\text { Drilling disturbance } \\
\text { Nannofossil zonation } \\
\text { Weight of original sample (g) }\end{array}$} & 2.15 & 2.61 & 6.49 & 8.03 & 8.52 & 13.95 & 15.82 \\
\hline & T5 & T5 & T5 & T5 & Ts & T8 & T8 \\
\hline & Slight & Slight & $\begin{array}{l}\text { Slight } \\
\text { CN15 }\end{array}$ & Slight & Slight & $\begin{array}{l}\text { Slight } \\
\text { CN14b }\end{array}$ & $\begin{array}{l}\text { Slight } \\
\text { CN14a }\end{array}$ \\
\hline & 20.18 & 21.60 & 16.39 & 15.19 & 18.16 & 13.25 & 17.95 \\
\hline Cavolinia inflexa & 2 & & & & 3 & & Barren \\
\hline Cavolinia tridentata & & & & & 2 & & " \\
\hline Clio convexa & & & & & 1 & & $"$ \\
\hline Clio pyramidata & & & & & 1 & 1 & $"$ \\
\hline Creseis acicula & 2 & 1 & & & 2 & & " \\
\hline Diacria quadridentata & 3 & & & & 2 & & $"$ \\
\hline Diacria trispinosa & 1 & 2 & 2 & & 1 & & " \\
\hline Hyalocylis striata & & & 1 & & 1 & & $"$ \\
\hline Limacina inflata & 2 & & & & 2 & & " \\
\hline Styliola subula & 36 & 33 & 42 & 5 & 110 & 8 & $\prime$ \\
\hline Peraclis sp. (ornament. lost) & & & & & 1 & & " \\
\hline
\end{tabular}


A

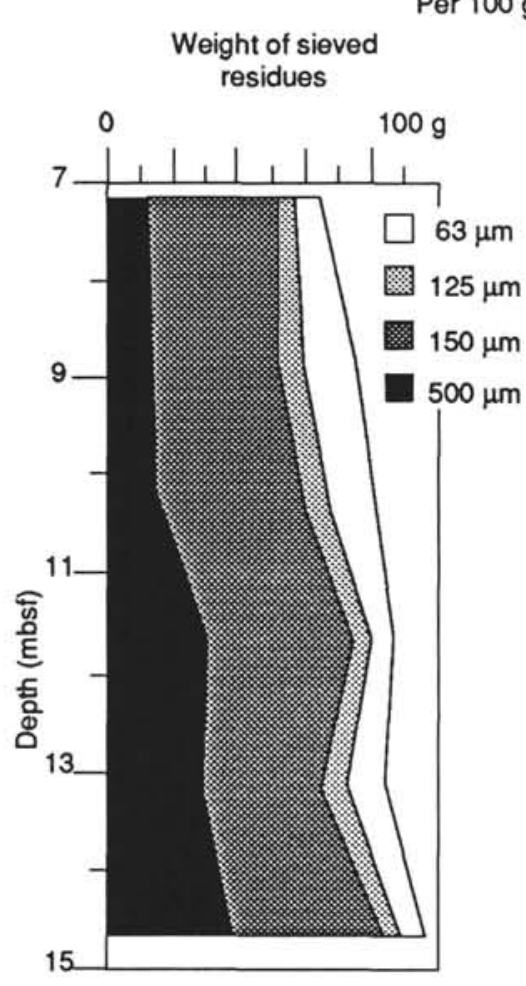

B

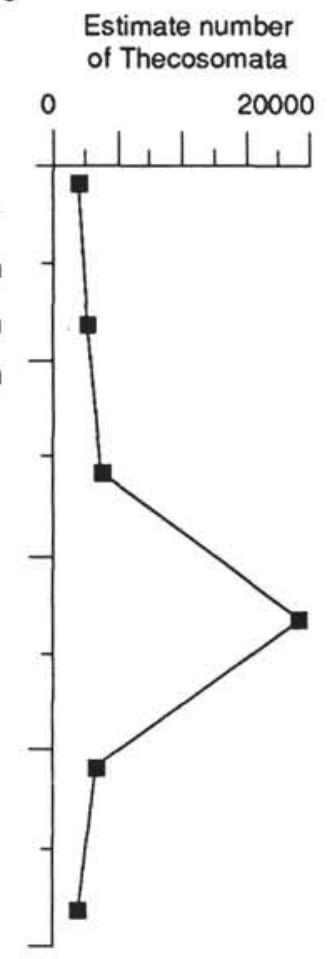

C

D

In O.S.

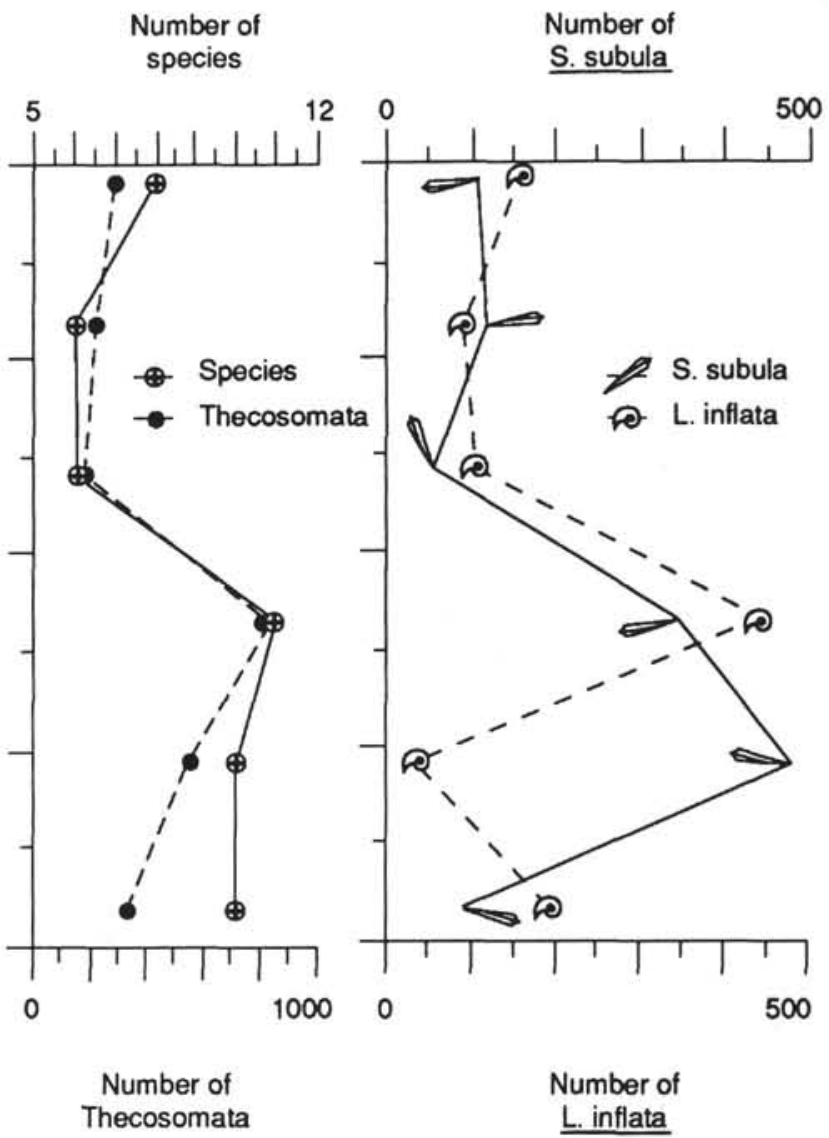

Figure 4. The distribution of Thecosomata and their species in samples from Cores $831 \mathrm{~A}-3 \mathrm{H}$ to $-10 \mathrm{X}$. A. Variation in the weight of residues per $100 \mathrm{~g}$ original sample (OS), using $63,125,150$, and $500 \mu \mathrm{m}$ mesh-size sieves. B. Estimate of the number of Thecosomata per $100 \mathrm{~g}$ of original samples. C. Comparison of the number of Thecosomata and the number of species found in original samples. D. Comparison of the frequency of Limacina inflata and Styliola subula in original samples.

Table 4. Numbers of identified Thecosomata in sieved residues larger than $500 \mu \mathrm{m}$ in grain size of every sample from Hole 831A.

\begin{tabular}{|c|c|c|c|c|c|c|c|c|c|c|c|c|c|c|c|c|c|}
\hline Section 134-831A- & $1 \mathrm{H}-1$ & $2 \mathrm{H}-1$ & $2 \mathrm{H}-1$ & $2 \mathrm{H}-2$ & $2 \mathrm{H}-3$ & $2 \mathrm{H}-4$ & $2 \mathrm{H}-5$ & $2 \mathrm{H}-5$ & $2 \mathrm{H}-6$ & $3 \mathrm{H}-\mathrm{I}$ & $3 \mathrm{H}-2$ & $3 \mathrm{H}-3$ & $3 \mathrm{H}-4$ & $3 \mathrm{H}-5$ & $53 \mathrm{H}-6$ & $8 \mathrm{X}-\mathrm{CC}$ & $10 \mathrm{X}-\mathrm{CC}$ \\
\hline Sample interval $(\mathrm{cm})$ & $81-84$ & $+87-89$ & $134-136$ & $6 \quad 73-77$ & $7 \quad 73-77$ & $18-22$ & $73-77$ & $73-77$ & $73-77$ & $75-80$ & $75-80$ & $75-80$ & $75-80$ & $75-80$ & $3075-80$ & $14-16$ & $27-28$ \\
\hline Depth (mbsf) & 0.81 & 5.27 & 5.74 & 6.63 & 8.13 & 9.08 & 9.63 & 11.13 & 12.63 & 7.15 & 8.65 & 10.15 & 11.65 & 13.15 & 14.65 & 48.5 & 58.27 \\
\hline Graphic lithology & SR2 & CB2 & CB2 & $\mathrm{CB} 2$ & CB2 & $\mathrm{CB} 2$ & CB2 & $\mathrm{CB} 2$ & $\mathrm{CB} 2$ & CB2 & CB2 & CB2 & $\mathrm{CB} 2$ & CB2 & CB2 & N3 & N4 \\
\hline Drilling disturbance & Mod. & High & High & Soupy & y Soupy & Soupy & High & Soupy & Mod. & Slight & t Soupy & Slight & Slight & Sligh & ht Slight & High & Mod \\
\hline Nannofossil zonation & & & & & & & & $\mathrm{CN} 15$ & & & & & & & & Barren & Barren \\
\hline Weight of original sample (g) & 14.52 & 13.65 & 13.71 & 9.21 & 8.71 & 9.15 & 9.63 & 12.46 & 11.41 & 14.51 & 8.36 & 4.76 & 4.29 & 16.85 & 17.93 & 42.39 & 18.44 \\
\hline Cavolinia gibbosa & & & & & & & & & & 1 & & & 1 & & & Barren & Barren \\
\hline Cavolinia globulosa & & & & & & & & & & & & & & & 1 & & \\
\hline Cavolinia inflexa & 2 & & & & 1 & 7 & 3 & 3 & 5 & 6 & 3 & & 6 & 4 & 1 & $"$ & $"$ \\
\hline Cavolinia longirostris & & & & & & & & & 1 & & & & & & & $"$ & $"$ \\
\hline Clio convexa & & 2 & 1 & & & & & & & & & & & 1 & & $"$ & $"$ \\
\hline Clio cuspidata & & & & & & & & & 1 & & & & & & & $"$ & " \\
\hline Clio pyramidata & & 1 & & & & 6 & 3 & 1 & $i$ & & $?$ & & 3 & 1 & & $"$ & " \\
\hline Creseis acicula & 1 & & & 2 & 2 & 4 & & & & & & & 5 & & & $"$ & $"$ \\
\hline Diacria quadridentata & & 5 & & 1 & 1 & 4 & 3 & 2 & 1 & 3 & 4 & & 5 & 3 & 3 & $"$ & $"$ \\
\hline Diacria trispinosa & & & 1 & $\mathrm{i}$ & i & & & & & & & & 1 & 1 & 1 & $"$ & " \\
\hline Hyalocylis striata & & & & & 1 & & & & & 1 & & 1 & 1 & & & $"$ & $"$ \\
\hline Limacina bulimoides & & 3 & 4 & 6 & 8 & 9 & 9 & & 6 & 6 & & 4 & 13 & 4 & 14 & " & $"$ \\
\hline Limacina inflata & 13 & 64 & 75 & 152 & 173 & 417 & 154 & 197 & 161 & 158 & 91 & 106 & 442 & 35 & 192 & $"$ & $"$ \\
\hline Limacina lesueuri & 2 & 3 & 4 & 2 & 1 & 10 & 8 & 9 & 5 & 6 & 3 & 6 & 10 & 11 & 15 & $"$ & $"$ \\
\hline Limacina trochiformis & & 2 & & & & & & & & & & 3 & & 2 & 5 & $"$ & $"$ \\
\hline Styliola subula & 2 & 35 & 4 & 117 & 103 & 167 & 82 & 130 & 126 & 108 & 117 & 55 & 344 & 479 & 93 & $"$ & $"$ \\
\hline
\end{tabular}


Table 5. Special specific characteristics of teloconchs, protoconchs, or posterior spines of the principal species collected in the western Pacific.

\begin{tabular}{|c|c|c|}
\hline Species & Teloconch & Protoconch or posterior spines \\
\hline & $\begin{array}{l}\text { Conical shell } \\
\text { Round transversal section }\end{array}$ & Protoconch \\
\hline Creseis acicula & $\begin{array}{l}\text { Longitudinal sides almost parallel } \\
\text { maximum diameter about Imm }\end{array}$ & $\begin{array}{l}\text { Longitudinal sides parallel } \\
2 \text { rings }\end{array}$ \\
\hline Creseis conica & $\begin{array}{l}\text { Longitudinal sides weakly divergent } \\
\text { maximum diameter about } 2 \mathrm{~mm}\end{array}$ & $\begin{array}{l}\text { Longitudinal sides weakly divergent } \\
\text { weak or absent constriction }\end{array}$ \\
\hline Creseis virgula & $\begin{array}{l}\text { Longitudinal sides strongly divergent } \\
\text { maximum diameter about } 2-2.5 \mathrm{~mm}\end{array}$ & $\begin{array}{l}\text { Longitudinal sides strongly divergent } \\
\text { strong constriction }\end{array}$ \\
\hline Creseis chierchiae & $\begin{array}{l}\text { Longitudinal sides weakly divergent } \\
\text { sometimes transverse ripples } \\
\text { maximum diameter about } 0.5 \mathrm{~mm}\end{array}$ & $\begin{array}{l}\text { Longitudinal sides weakly divergent } \\
\text { strong constriction }\end{array}$ \\
\hline \multirow[t]{2}{*}{ Styliola subula } & $\begin{array}{l}\text { Longitudinal groove running obliquely } \\
\text { on almost all the dorsal length } \\
\text { maximum diameter about } 1.5 \mathrm{~mm}\end{array}$ & short and sharp \\
\hline & Oval transversal section & \\
\hline \multirow[t]{2}{*}{ Hyalocylis striata } & $\begin{array}{l}\text { Strong transverse ripples, truncate shell } \\
\text { maximum diameter about } 1 \mathrm{~mm}\end{array}$ & Decaying; very rare \\
\hline & $\begin{array}{l}\text { Subcylindrical shell } \\
\text { Oval transversal section }\end{array}$ & \\
\hline \multirow[t]{2}{*}{ Cuvierina columnella } & $\begin{array}{l}\text { Aperture lemniscate-shaped, truncate } \\
\text { shell } \\
\text { maximum diameter about } 2 \mathrm{~mm}\end{array}$ & Decaying; very rare \\
\hline & $\begin{array}{c}\text { Subpyramidal shell } \\
\text { (Lateral spines, wide open aperture) } \\
\text { Lenticular transversal section }\end{array}$ & \\
\hline \multirow[t]{2}{*}{ Clio polita } & Almost smooth very flat shell & Spherical \\
\hline & Triangular section & \\
\hline Clio pyramidata & $\begin{array}{l}\text { Lateral spines, angular in cross section } \\
3 \text { dorsal longitudinal ridges }\end{array}$ & Oval \\
\hline Clio convexa & $\begin{array}{l}\text { Lateral spines flat in cross section } \\
1 \text { dorsal longitudinal ridge }\end{array}$ & Blunt equilateral triangular \\
\hline \multirow[t]{4}{*}{ Clio cuspidata } & $\begin{array}{l}\text { Long lateral and dorsal spines } \\
\text { deep and large transversal ripples }\end{array}$ & Spherical with an apical spine \\
\hline & $\begin{array}{c}\text { Swollen Shell } \\
\text { (Lateral spines, restricted aperture) }\end{array}$ & \\
\hline & Lenticular transversal section & \\
\hline & Thick dorsal lip with strips & \\
\hline Diacria trispinosa & Dorso-ventrally flattened & $\begin{array}{l}\text { Spherical; juvenile shell with flat } \\
\text { sides/persistent }\end{array}$ \\
\hline \multirow[t]{2}{*}{ Diacria quadridentata } & Swollen & $\begin{array}{l}\text { Oval elongated juvenile shell with flat } \\
\text { sides decaying }\end{array}$ \\
\hline & Thin dorsal lip & Posterior spine \\
\hline Cavolinia inflexa & Dorso-ventrally flattened right dorsal lip & Weakly dorsally curved \\
\hline Cavolinia gibbosa & $\begin{array}{l}\text { Swollen, ventral side sharply angular } \\
\text { protruding }\end{array}$ & Curved except the extremity \\
\hline Cavolinia tridentata & $\begin{array}{l}\text { Thick brown shell, high dorsal } \\
\text { transverse ribs }\end{array}$ & Straight \\
\hline Cavolinia uncinata & Brown shell, obvious dorsal ribs & Strongly curved dorsally \\
\hline Cavolinia globulosa & Swollen, almost spherical & Strongly curved dorsally \\
\hline Cavolinia longirostris & $\begin{array}{l}\text { Dorsal apertural lip like a beak, channel- } \\
\text { shaped flattened lateral spines }\end{array}$ & Truncated \\
\hline
\end{tabular}

Note: For the genus Creseis we follow the terminology of Rampal (1985). 
Table 6. Expected Thecosomata assemblage in the studied area.

\begin{tabular}{|c|c|c|c|}
\hline Common species & & Present species & \\
\hline Cavolinia gibbosa & $\mathrm{cw}$ & Cavolinia globulosa & $\mathrm{t}$ \\
\hline Cavolinia inflexa & $\mathrm{cw}$ & Cavolinia longirostris & ww \\
\hline Cavolinia tridentata & ww & Cavolinia uncinata & $t$ \\
\hline Clio cuspidata & ww & Clio convexa & $\mathrm{t}$ \\
\hline Diacria quadridentata & ww & Clio pyramidata & $\mathrm{cw}$ \\
\hline Diacria trispinosa & ww & Creseis acicula & ww \\
\hline Limacina lesueuri & $\mathrm{cw}$ & Creseis virgula & ww \\
\hline \multirow[t]{5}{*}{ Styliola subula } & $\mathrm{cw}$ & Cuvierina columnella & ww \\
\hline & & Hyalocylis striata & $t$ \\
\hline & & Limacina bulimoides & $\mathrm{cw}$ \\
\hline & & Limacina inflata & ww \\
\hline & & Limacina trochiformis & $\mathrm{t}$ \\
\hline
\end{tabular}

Note: Based on the "crude semiquantitative maps intended as a general synthesis of the zoogeographic patterns of euthecosomatous pteropods" by Bé and Gilmer (1977). For every species the distribution is indicated by the following abbreviations after Bé and Gilmer: $w w=$ warm water cosmopolitan province, $\mathrm{cw}=$ subtropical central water masses, and $\mathrm{t}=$ tropical province. 


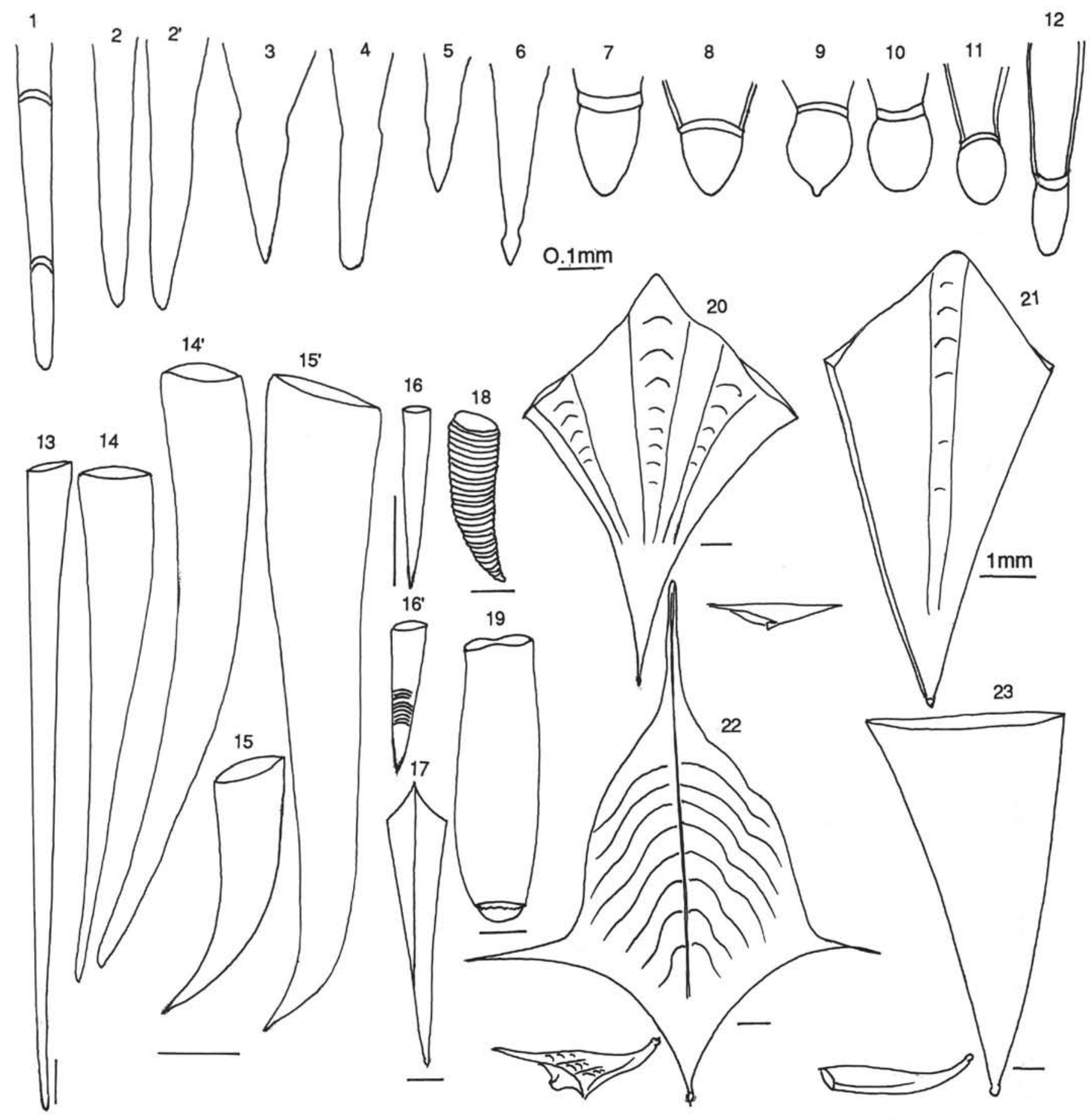

Plate 1A. Uncoiled thecosomatous protoconchs and teloconchs from the western Pacific. 1-12. Protoconchs (scale bar $0.1 \mathrm{~mm}$ for Figs. 1-4; $0.2 \mathrm{~mm}$ for Figs. 5-12), (1) Creseis acicula, (2, 2') Creseis conica, (3) Creseis virgula, (4) Creseis chierchiae, (5) Styliola subula, (6) Cuvierina columnella, protoconch and juvenile shell, (7) Clio pyramidata, (8) Clio convexa, (9) Clio cuspidata, (10) Clio polita, (11) Diacria trispinosa, (12) Diacria quadridentata, protoconch and juvenile shell. 13-23. Teloconchs (scale bar $1 \mathrm{~mm}),(13)$ Creseis acicula, $\left(14,14^{\prime}\right)$ Creseis conica, $\left(15,15^{\prime}\right)$ Creseis virgula, $\left(16,16^{\prime}\right)$ Creseis chierchiae, (17) Styliola subula, (18) Hyalocylis striata, (19) Cuvierina columnella, (20) Clio pyramidata, (21) Clio convexa, (22) Clio cuspidata, (23) Clio polita. 

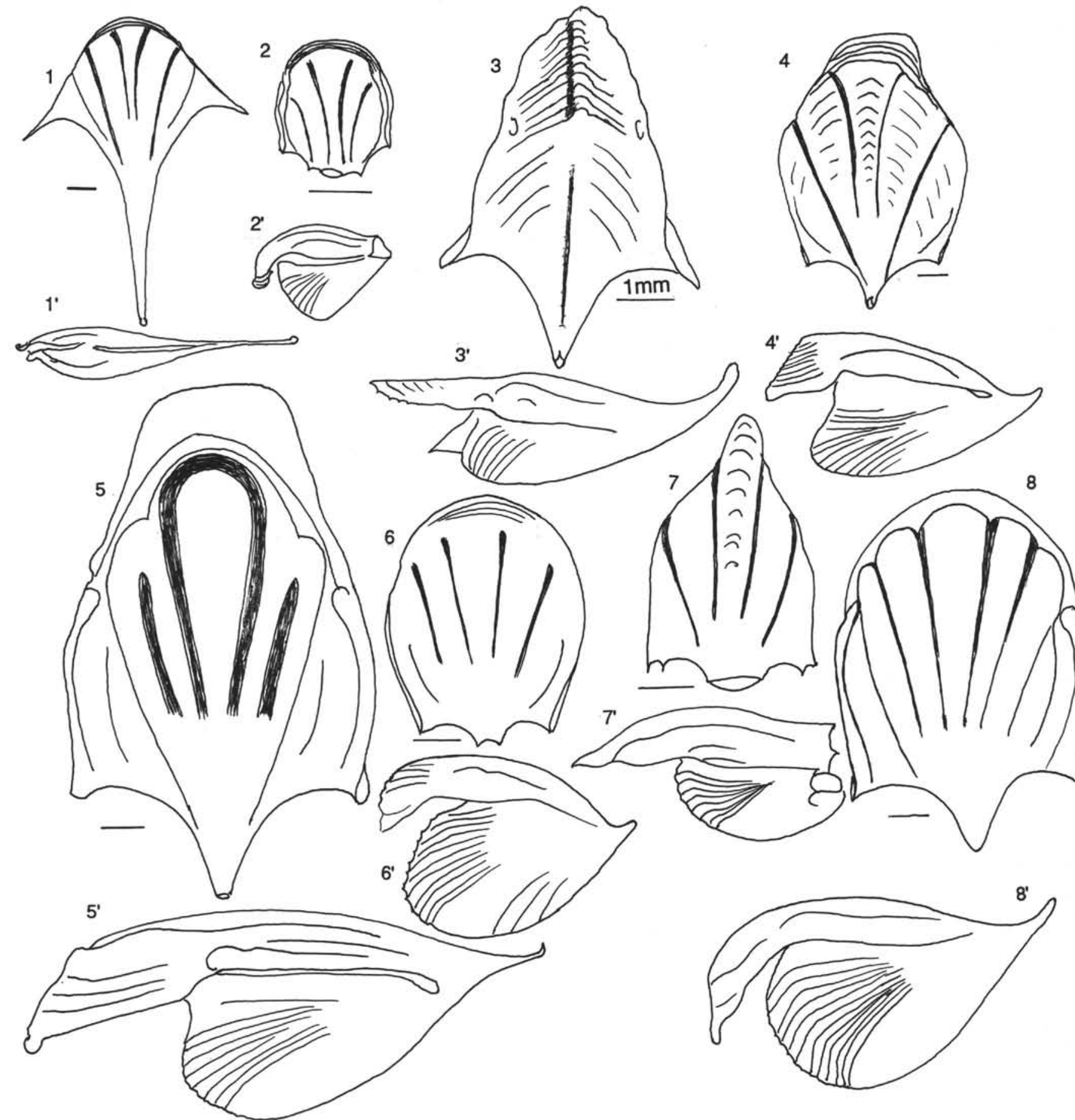

Plate 1B. Uncoiled thecosomatous teloconchs from the western Pacific, dorsal and profile views (scale bar $1 \mathrm{~mm}$ ). 1, 1'. Diacria trispinosa. 2,2'. Diacria quadridentata. 3, 3'. Cavolinia inflexa. 4, 4'. Cavolinia gibbosa. 5, 5'. Cavolinia tridentata. 6, 6'. Cavolinia globulosa. 7, 7'. Cavolinia longirostris. 8, 8'. Cavolinia uncinata. 

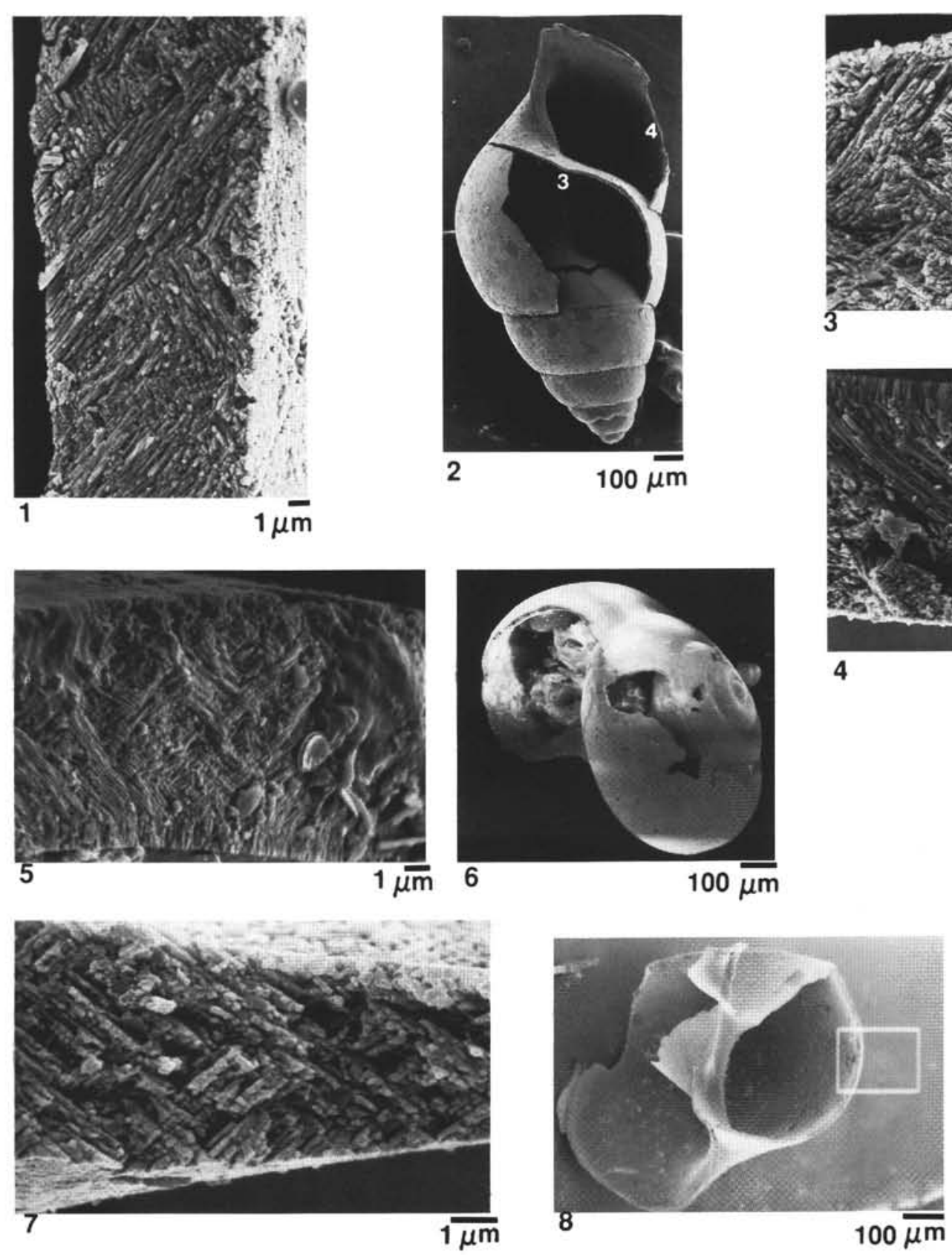
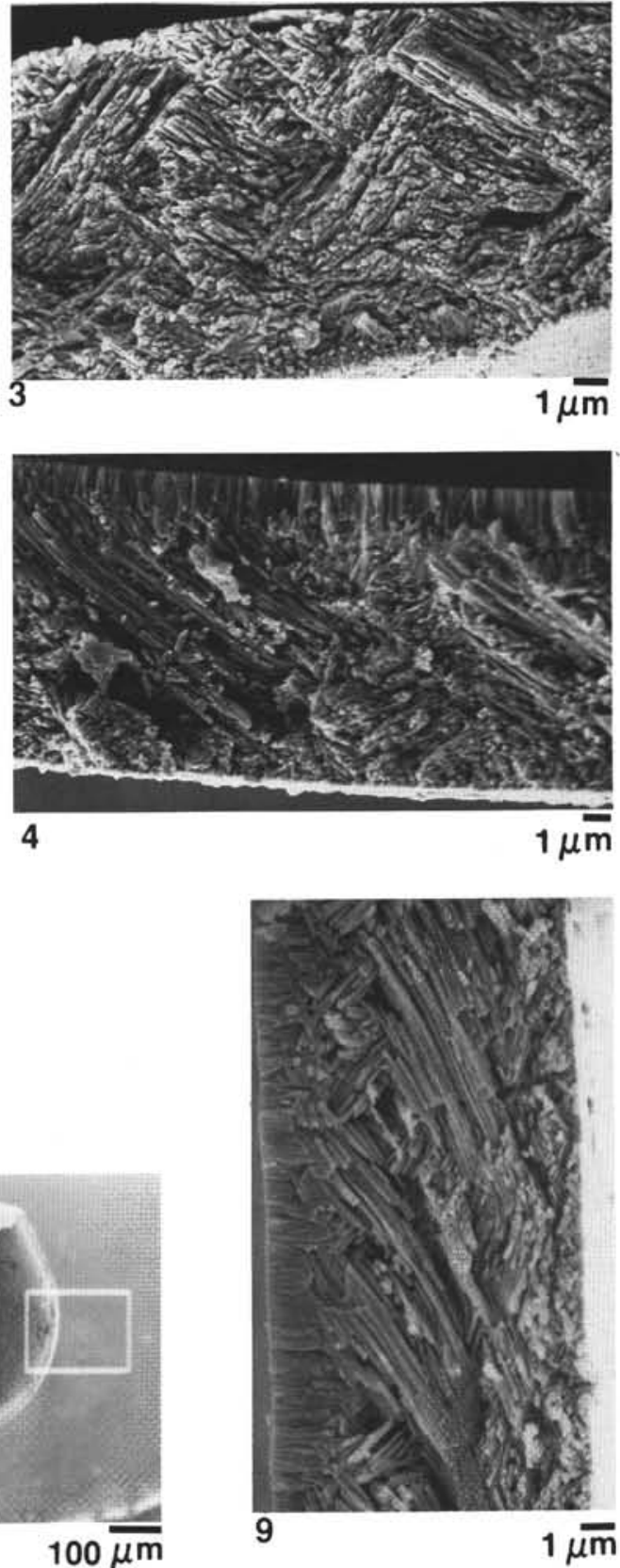

Plate 2. Rod-type crossed lamellar structure. 1-4. Limacina bulimoides, Sample 134-831A-3H-5, 75-80 cm, (1) longitudinal section at the penultimate coil, (3) subtransverse section of the same individual, (4) longitudinal section at the margin of the aperture (note the inner prismatic layer). 5, 6. Limacina lesueuri, Sample 134-831 A-3H-4, 75-80 cm, (5) longitudinal section near the aperture (note the inner prismatic layer), (6) profile of the same individual. 7-9. Limacina trochiformis, Sample 134-831A-3-6, 75-80 cm, (7) transverse section, (8) axial section of the same individual, (9) longitudinal section with an inner prismatic layer. 

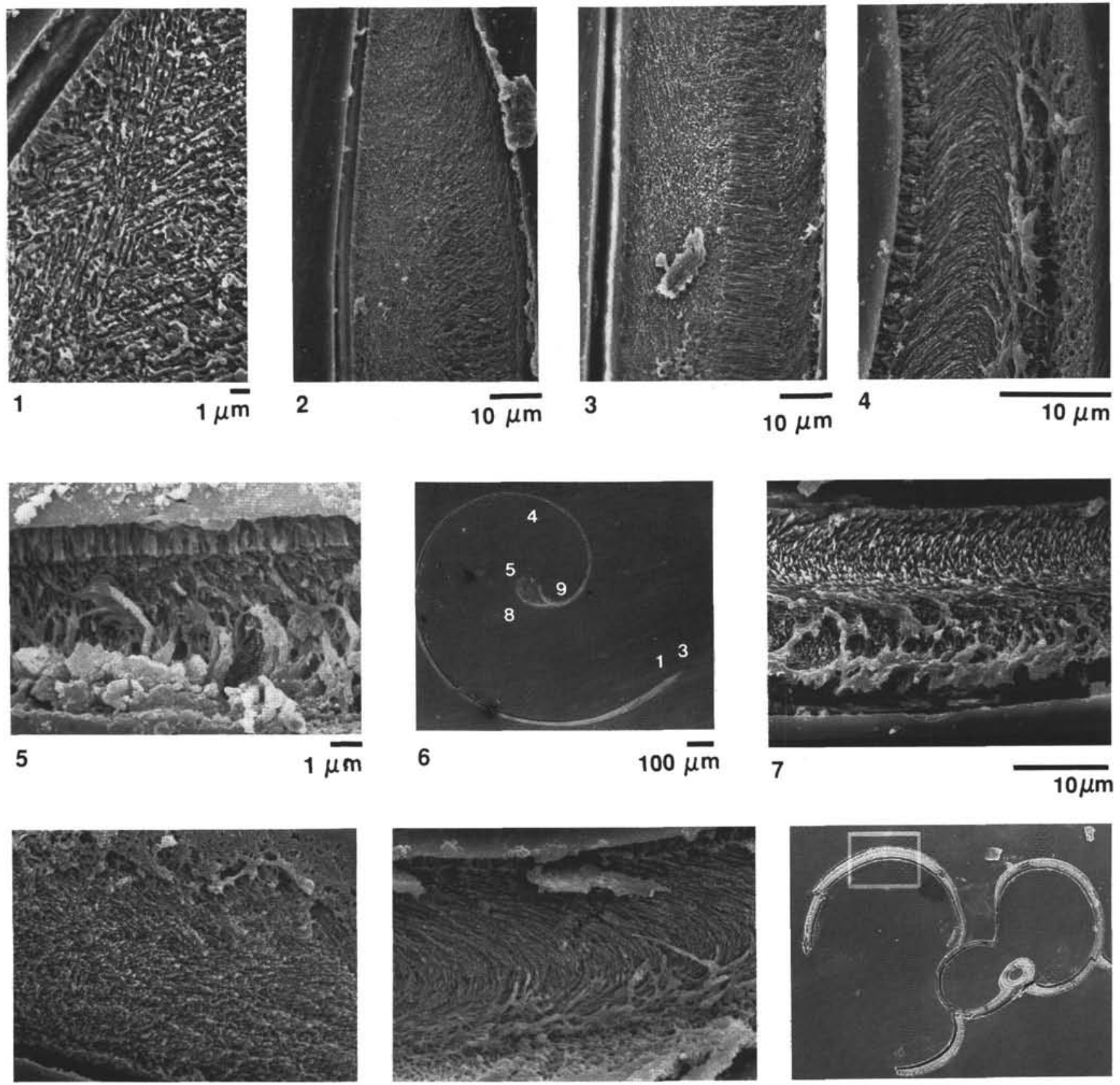

8

$1 \mu \bar{m}$

9

$1 \mu \mathrm{m}$

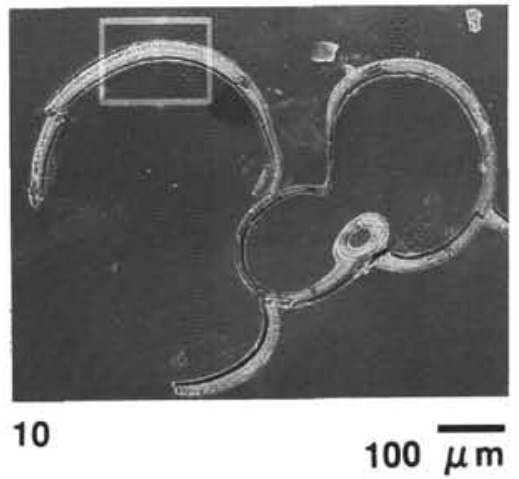

Plate 3. Study of two Limacina inflata embedded in araldite. 1-3. Detail of the structures found near the aperture, (1) crossed-acicular, (2) locally crossed-acicular, locally confused, (3) locally prismatic. 4. Helical structure. 5. Inner prismatic layer away from the aperture. 6. Transversal section of the first individual illustrated in detail of Figures 1-5, 8-9. 7. Typical helical structure of specimen, inner wall at the top of the illustration; see also Figure 10. 8,9. Sections of the apex of the first specimen, see Figure 6 for location, (8) confused structure, (9) typical helical structure. 10. Subaxial section. The rectangle to locate Figure 7. 

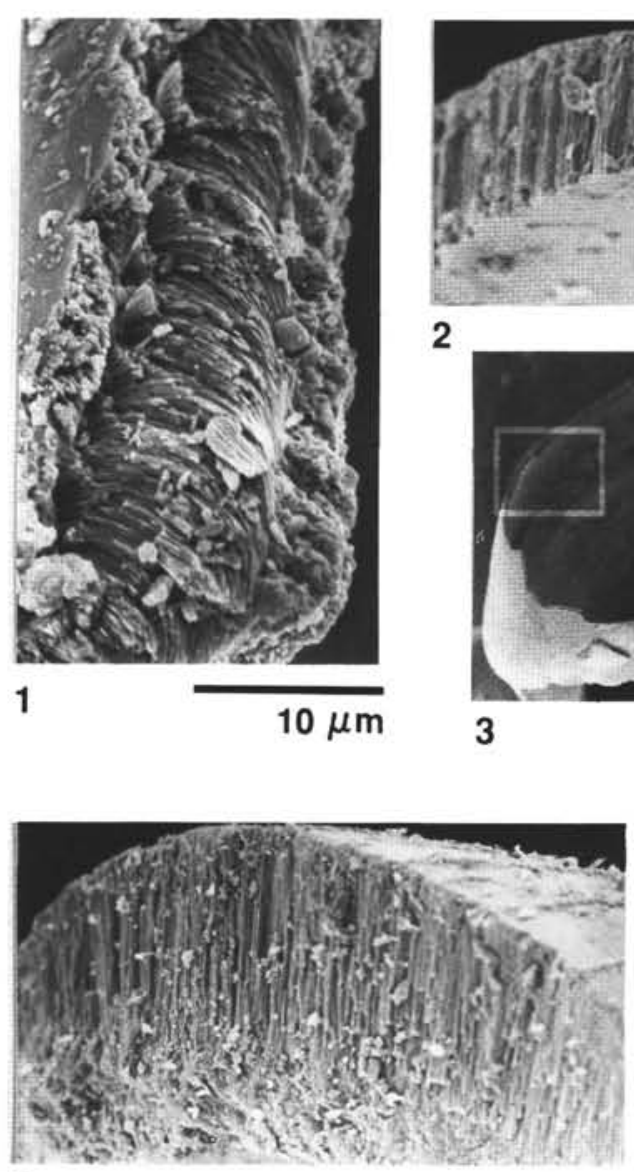

5

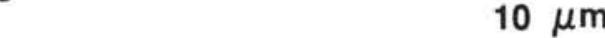

2
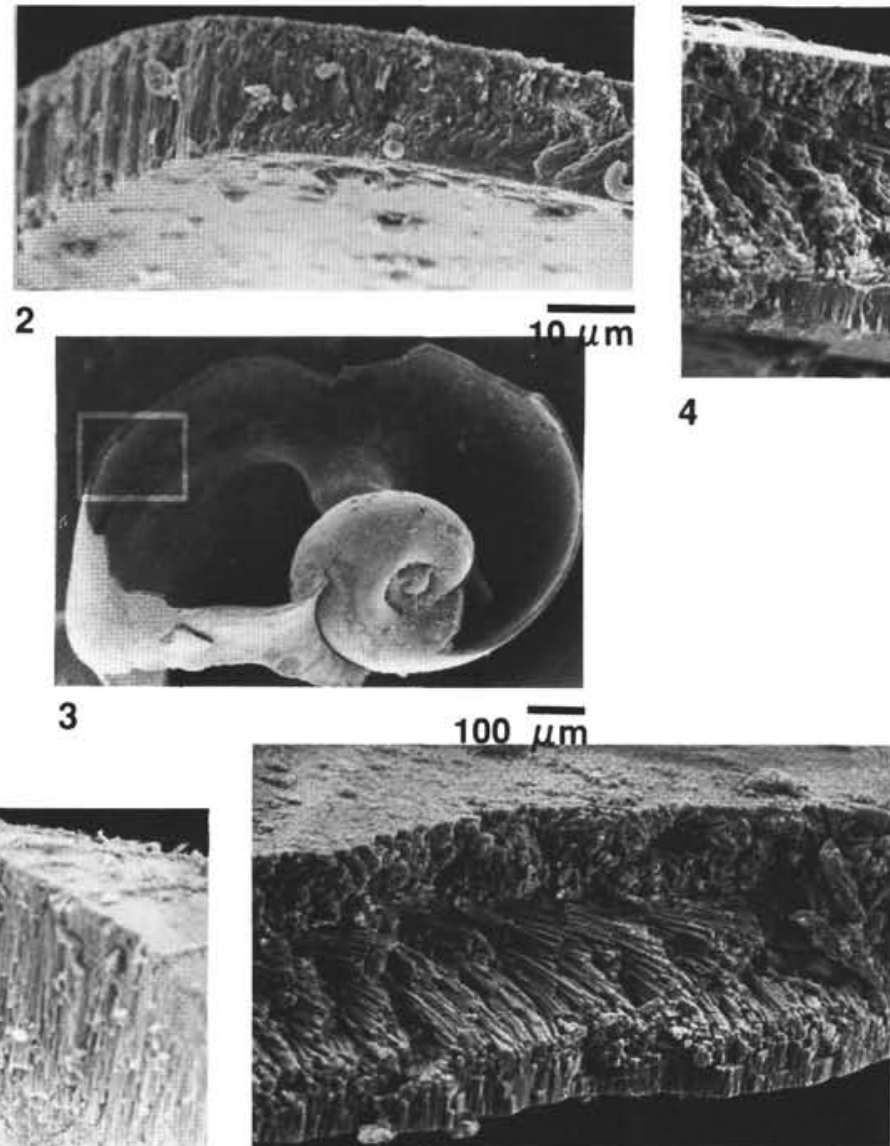

6
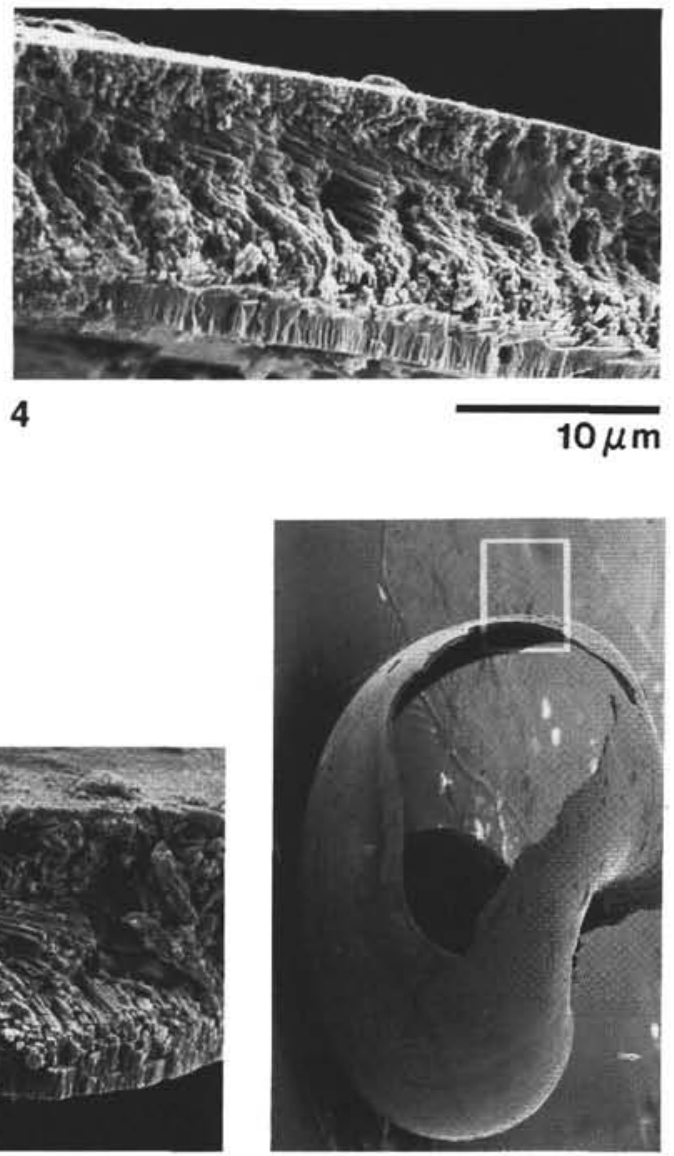

7

$100 \overline{\mu \mathrm{m}}$

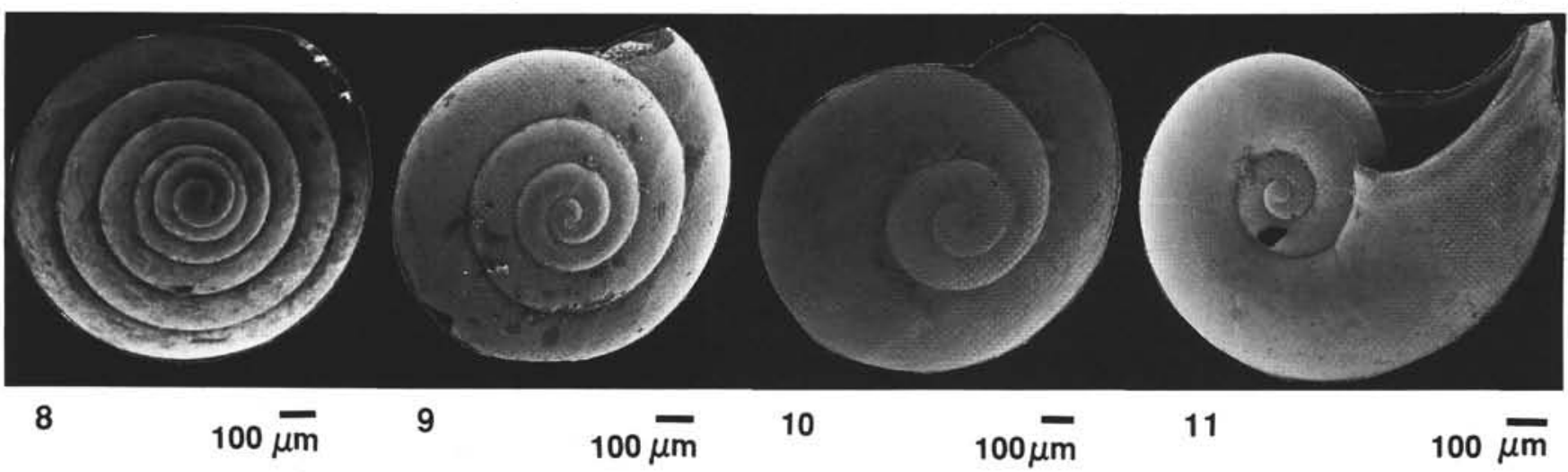

Plate 4. 1-7. Two Limacina inflata, Sample 134-831A-3H-4, 75-80 cm, $(1,2)$ sublongitudinal sections of specimen (3) (2, passage from helical to prismatic structure); (5) prismatic structure in the apertural zone of specimen (3) (note the longitudinal striations); $(4,6)$ two longitudinal sections showing the helical structure of specimen (7). 8-11. Apical views of the following species of Limacina, (8) L. bulimoides, (9) L. lesueuri, (10) L. trochiformis, (11) L. inflata. 

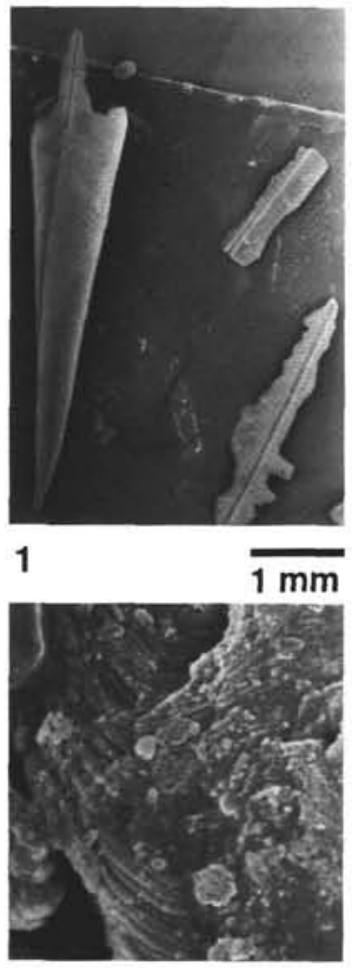

5
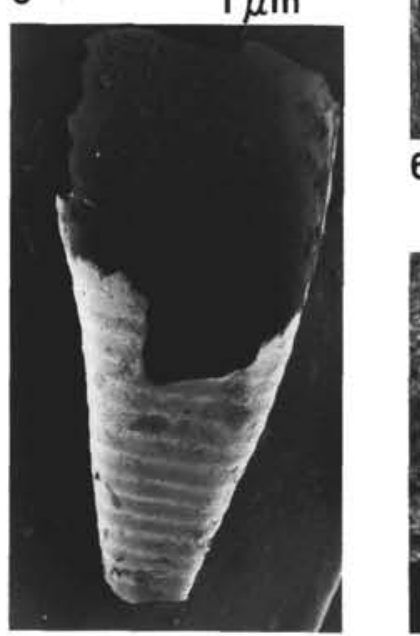

8
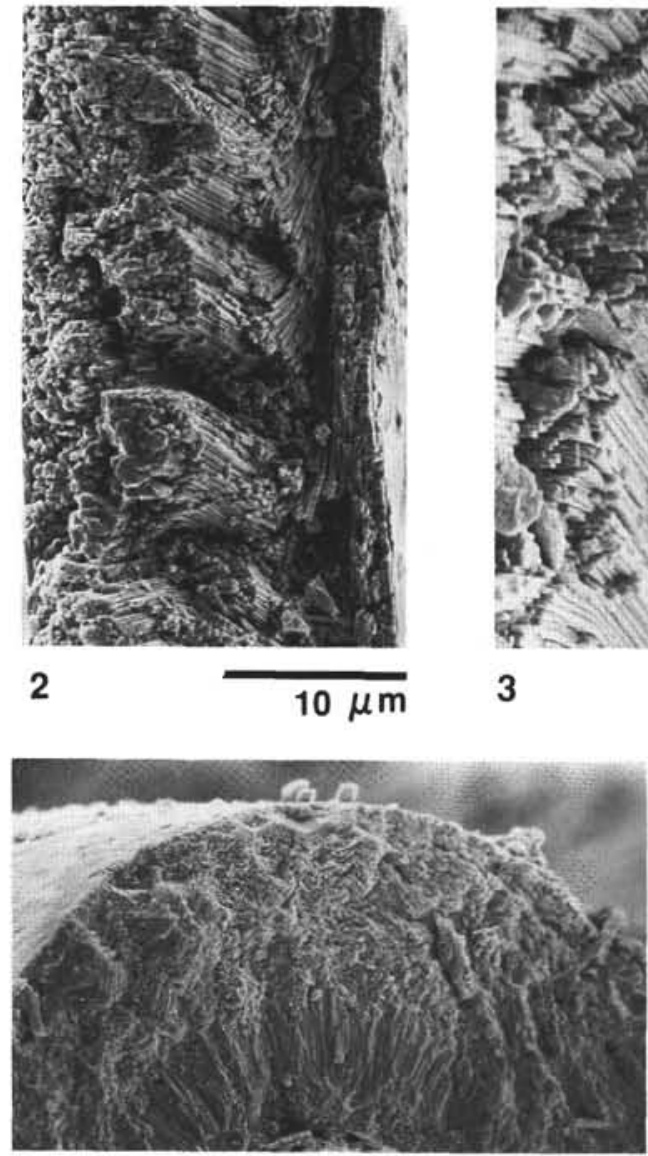

6

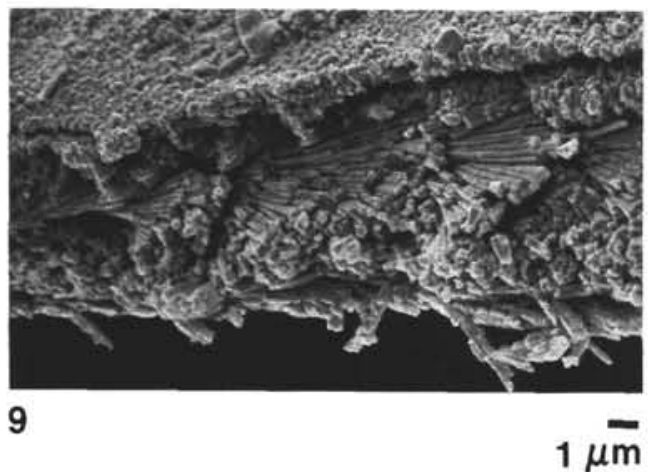

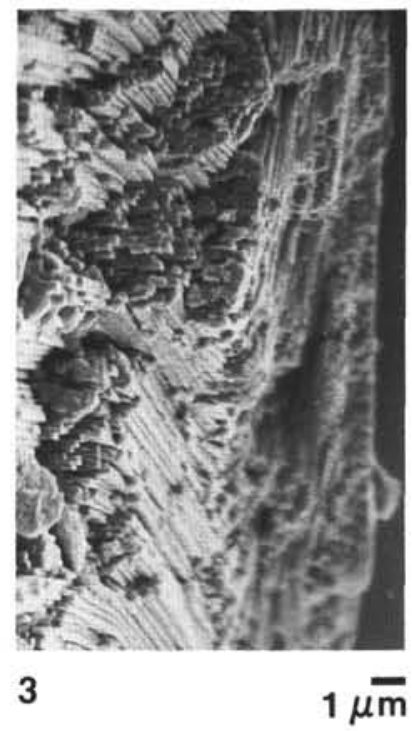

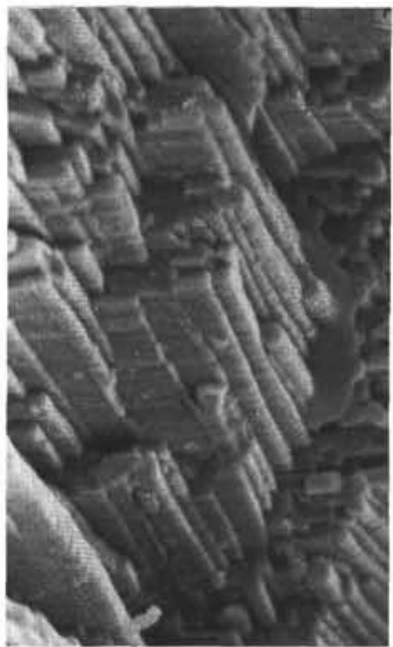

4

$\overline{1 \mu \mathrm{m}}$

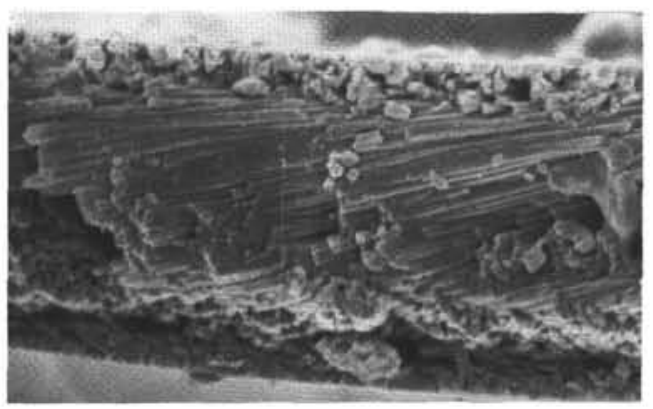

7

$1 \mu \bar{m}$

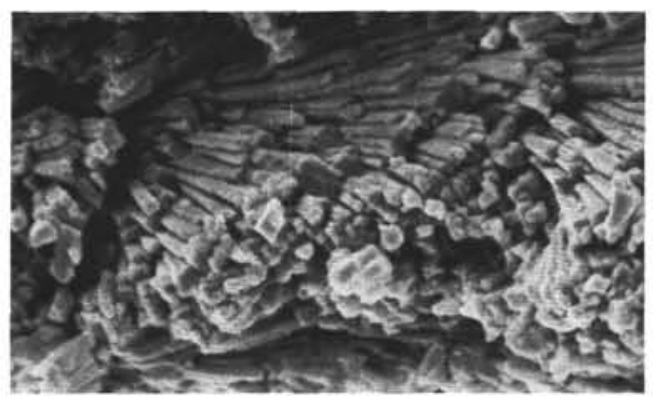

10

$1 \overline{\mu \mathrm{m}}$

Plate 5. Helical structure of Styliola subula and Hyalocylis striata, Sample 134-831A-3H-4, 75-80 cm. 1-7. Styliola subula, (1, broken individual with two identifiable fragments, longitudinal groove running obliquely, $2-4$, longitudinal sections; 5 , tangential section; 6 , transverse section of the longitudinal groove showing a thick prismatic inner layer; 7 , transverse section). 8-10. Hyalocylis striata (9, 10, longitudinal sections). 

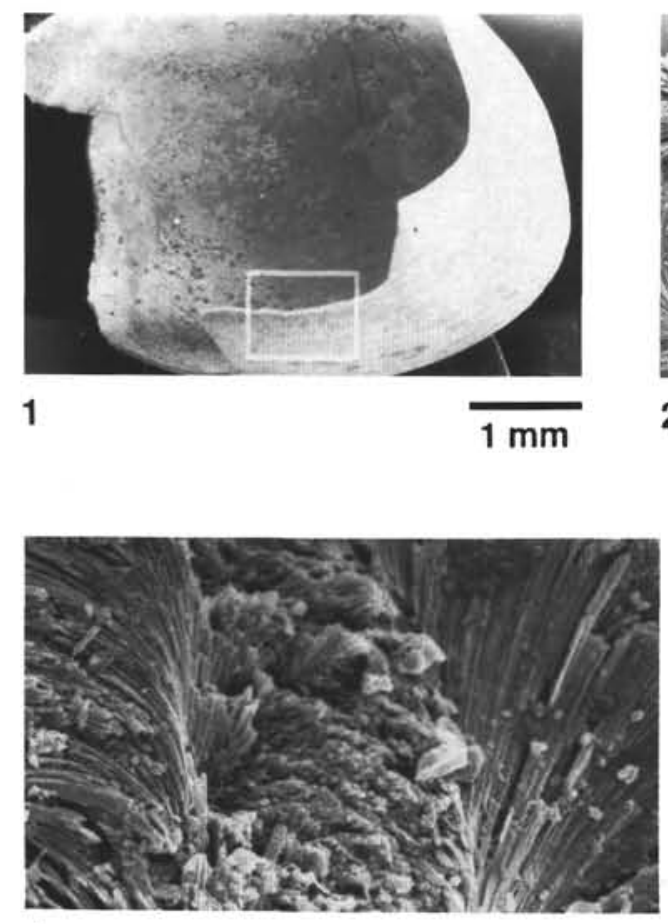

4

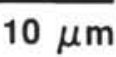

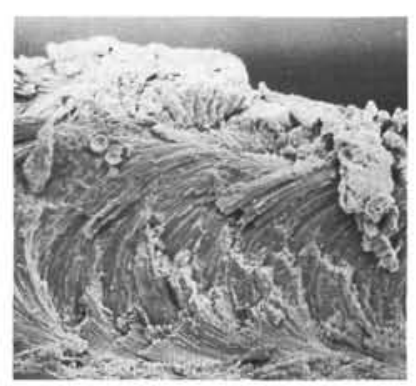

2

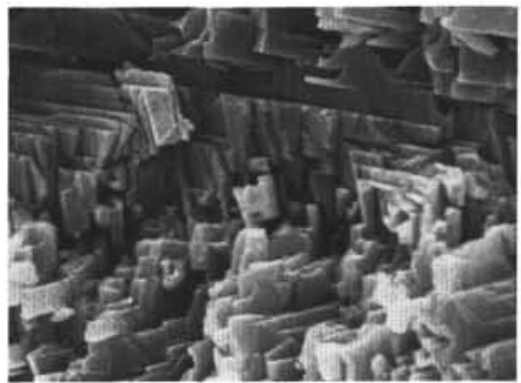

5
$10 \mu \mathrm{m}$

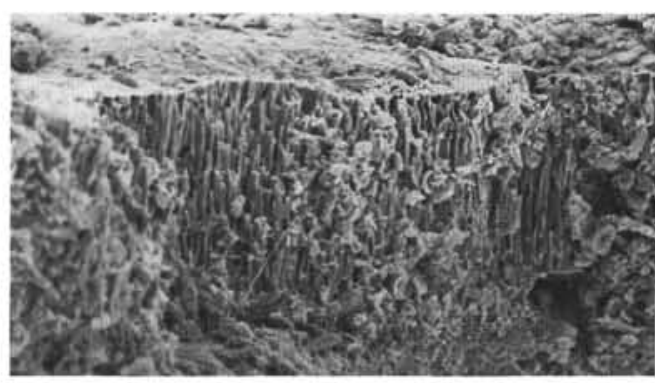

3

$10 \mu \mathrm{m}$

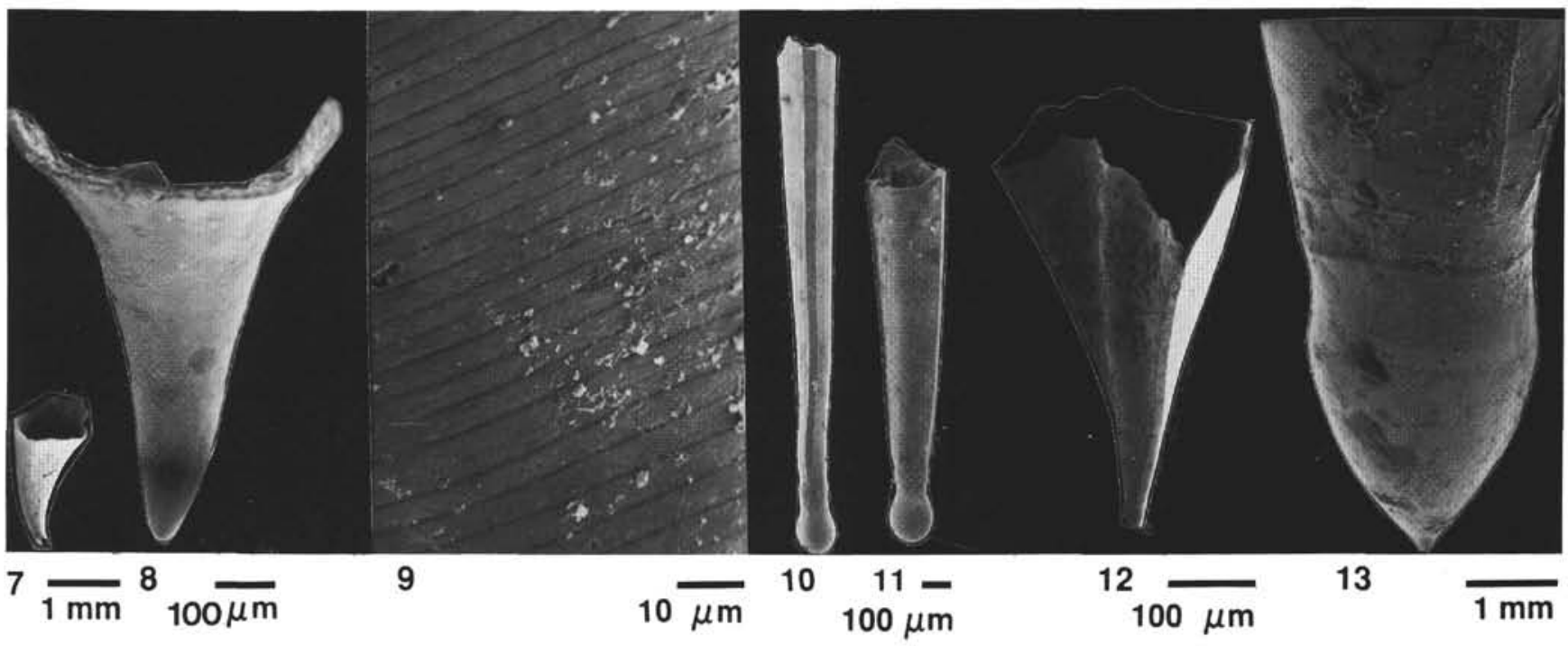

Plate 6. 1-6. Examples of structures of the shells of Cavoliniidae. (1-3) Cavolinia globulosa, Sample 134-831A-3H-4, 75-80 cm), (2) longitudinal section of the ventral face, (3) prismatic structure of the dorsal lip, (4) Cavolinia gibbosa, Sample 134-831A-3H-4, 75-80 cm, subtransverse section of the posterior spine. $(5,6)$ Diacria quadridentata, Sample 134-831A-2H-4, 18-22 cm, (5) detail of a longitudinal section of the ventral face, (6) longitudinal section of the ventral face crossing transverse ribs. 7-13. Examples of identifiable shell remains and protoconchs, (7-9) two protoconchs of Cavolinia inflexa and their superficial ornamentation, Sample 134-831-3H-4, 75-80 cm, (10, 11) Diacria trispinosa protoconchs, Sample 134-831A-3H-4, 75-80 cm, (10) profile, (11) ventral face. $(12,13)$ Clio convexa, Sample 134-831A-2H-4, 18-22 cm, (12) damaged specimen, (13) protoconch. 